\title{
HYDROCARBON GENERATION AND MIGRATION FROM BARREMIAN - APTIAN SOURCE ROCKS, NORTHERN ORANGE BASIN, OFFSHORE WESTERN SOUTH AFRICA: A 3D NUMERICAL MODELLING STUDY
}

\author{
C.A. Samakinde ${ }^{1,2 *}$, J. M. van Bever Donker', \\ R. Durrheim ${ }^{2}$ and M. Manzi ${ }^{2}$
}

A 3D numerical modelling workflow was applied to the Barremian-Aptian source rock interval in a shelfal to lower slope area of the northern Orange Basin, offshore western South Africa. The main objective was to investigate the timing of hydrocarbon generation and migration. Hydrocarbon migration has previously been investigated in the south of the basin by relating gas escape features with structural elements as seen on seismic sections, but migration pathways are still poorly understood.The modelling study was based on data from three exploration wells (AO-I,AE-I and AF-I) together with 42 2D seismic sections totalling $3537 \mathrm{~km}$ in length, and a 3D seismic cube covering an area of $750 \mathrm{sq} . \mathrm{km}$.

Modelled formation temperatures increase from north to south in the study area and were consistent with downhole temperatures at well locations. However, there is variation between measured and modelled values of vitrinite reflectance (VR), especially in the Turonian and Cenomanian intervals. The measured VR is lower than the modelled VR within the Turonian section in the north of the study area, suggesting that erosion has affected the thermal maturity of the sediments. However, in the Cenomanian interval, the measuredVR is higher than the modelled VR. Uplift, increased erosion in the hinterland and sediment transport to the coastal areas resulted in Cenomanian progradation of the Orange Basin fill. This together with a heat flow pulse resulted in increased thermal maturities in the study area.

Modelling results show that hydrocarbon generation began in the central part of the study area by I I $6 \mathrm{Ma}$ and reached a peak in the Late Cretaceous (65 Ma). Hydrocarbon migration began at about I 10 Ma with an expulsion efficiency of 0.77 . At the present day, $\sim 100 \%$ transformation of reactive kerogen into hydrocarbons has taken place in the central part of the study area, with random gas migration within Cenomanian and Albian reservoirs. Modelled oil migration likely influenced by hydrodynamic factors is down-dip (westwards), towards deeper-water, more distal parts of the basin.

Gas saturation on a reactivated listric fault, which was $\sim 100 \%$ saturated at $93 \mathrm{Ma}$, declined to $\sim 15 \%$ by 65 Ma.This decrease in gas saturation is linked to uplift of the African margin in the Late Cretaceous which resulted in fault reactivation and re-migration of gas.

Despite the uncertainties which are associated with petroleum systems modelling, the study provides an insight into hydrocarbon migration in the northern part of the Orange Basin and contributes to the de-risking of future oil and gas exploration in this area.

\footnotetext{
'Department of Earth Sciences, University of the Western Cape, Capetown, South Africa.

${ }^{2}$ The School of Geosciences, University of the Witswatersrand, Johannesburg, South Africa.

*Corresponding author, chrissamakinde@gmail.com
}

Key words: Hydrocarbon generation, migration, petroleum system, modelling, Cretaceous, Barremian, Aptian, source rock, Orange Basin, South Africa, 


\section{INTRODUCTION}

Passive continental margins such as the Orange Basin offshore western South Africa (Fig. 1A) have witnessed a significant increase in interest from explorers over the last decade, and the ratio of hydrocarbon discoveries in passive margin settings to new global reserves has increased from $40 \%$ in 2008 to $80 \%$ in 2012 (Wen et al., 2016). 3D petroleum systems models have contributed to these successes as they examine how basin evolution, depositional systems and structural features interact in time and space. In addition, they investigate the conditions in which hydrocarbon accumulations may occur and the factors that influence migration (Welte et al., 1997). Structures in the Orange Basin are typical of those of a passive margin basin, with listric and normal faults associated with grabens and half grabens, most of which are oriented parallel to the coastline (Broad et al., 2007). Previous studies (Brown et al., 1996; Muntingh, 1993) have detailed the sequence stratigraphy and sedimentary fill of the basin (Fig. 2) which consists of Lower Cretaceous to Quaternary successions overlying rifted crystalline basement including gneisses, granite, acid lavas and Karoo-aged sediments (Petroleum Agency SA, 2006).

Exploration in the Orange Basin began in 1974, and 30 exploration wells have so far been drilled in water depths ranging from $200 \mathrm{~m}$ to $2000 \mathrm{~m}$ resulting in the discovery of the Kudu and Ibhubesi gas fields (Petroleum Agency SA, 2006). The Kudu field is located in the Namibian sector of the basin (Fig. 1A) while Ibhubesi is located to the south, offshore South Africa. Neither discovery has yet been developed because of technical and economic factors. Reservoir rocks at Kudu consist of Barremian aeolian sandstones while those at Ibhubesi are of Albian - Cenomanian age; seals in the Ibhubesi area are provided by Cenomanian mudstones.

Two main source rock units have been identified in the Orange Basin: Barremian-Aptian and Cenomanian - Turonian (Fig. 2A). The principal petroleum system is sourced by Barremian - lower Aptian shales with TOC values ranging from 3 to $15 \%$ (van der Spuy, 2003; Petroleum Agency SA, 2006) or 0.6 to $3 \%$ (Campher, 2009). These source rocks have a hydrogen index of up to $200 \mathrm{mg} \mathrm{HC} / \mathrm{g}$ with a vitrinite reflectance of 0.9-2.0\% $\mathrm{R}_{\mathrm{o}}$ (Adekola et al., 2012; van der Spuy, 2003). The Cenomanian - Turonian source rock is in general immature, although it may be sufficiently mature for oil generation in down-dip parts of the basin because of overburden effects which could induce thermal maturity (Jungslager, 1999).

Previous studies in the southern part of the Orange Basin, offshore South Africa (Boyd et al., 2011; Kuhlmann et al., 2010), tentatively identified hydrocarbon migration pathways from the mapping of faults in close proximity to gas-escape features observed on seismic sections. In spite of the prevalence of such gas-escape features, migration pathways are still poorly understood. Studies by Campher (2009) and Hartwig (2014) inferred that hydrocarbon generation in the southern Orange Basin is linked to rapid burial of source rocks in the mid- to Late Cretaceous, and to increased basal heatflow due to margin uplift in the Miocene. In these studies, migration occurred along Aptian, Albian and Cenomanian sandstones which served as carrier beds. However, the potential influence of faults on the migration pathways was not adequately investigated.

This paper presents a 3D modelling study of Barremian-Aptian source rocks in the northern part of the Orange Basin. The purpose was to investigate the timing of hydrocarbon generation and expulsion from the source rocks; to use Hybrid Darcy Flowpath migration modelling to predict hydrocarbon migration pathways and the potential influence of faults on the pathways; and to evaluate the possibility of hydrocarbon accumulations within the study area.

\section{Regional geology: tectonic evolution and stratigraphy}

The Orange Basin straddles the offshore border between Namibia and South Africa (Fig. 1A) and is located on a volcanic passive margin (Seranne and Anka, 2005; Light et al., 1993; Menzies et al., 2002). The basin is defined by the Kudu arch to the north and the Agulhas-Columbine arch in the south. Late Jurassic break-up of west Gondwana, probably induced by the Tristan da Cunha hot-spot, was followed by widespread flood basalt volcanism (Morgan, 1971). Margin evolution culminated in rifting and separation of the South American and African plates in the Late Jurassic and Early Cretaceous (Macdonald et al., 2003; Brown et al., 1996).

The tectonic history of the Orange Basin can be divided into pre-, syn- and post-rift phases (Brown et al., 1996) (Fig. 2A). The pre-rift succession is overlain by pre-Barremian basaltic lavas within the central rift province and by coarse continental clastics and fluvial and lacustrine sediments associated with volcanic deposits in more marginal areas (Broad et al., 2007). The initial rift sequence (syn-rift 1) was deposited in a NE-trending intracontinental graben, and was terminated at the onset of sea-floor spreading by the end of the Hauterivian (Granado et al., 2009). The sequence is overlain by a transitional, rift-to-drift sequence of Barremian-Aptian age (horizons 6At1 13At1; Fig. 2A) with a thickness of up to $2000 \mathrm{~m}$ in the central part of the margin (Hartwig et al., 2012).

The Albian-Cenomanian post-rift succession is composed of alternating marine and nonmarine sediments deposited in response to marine 


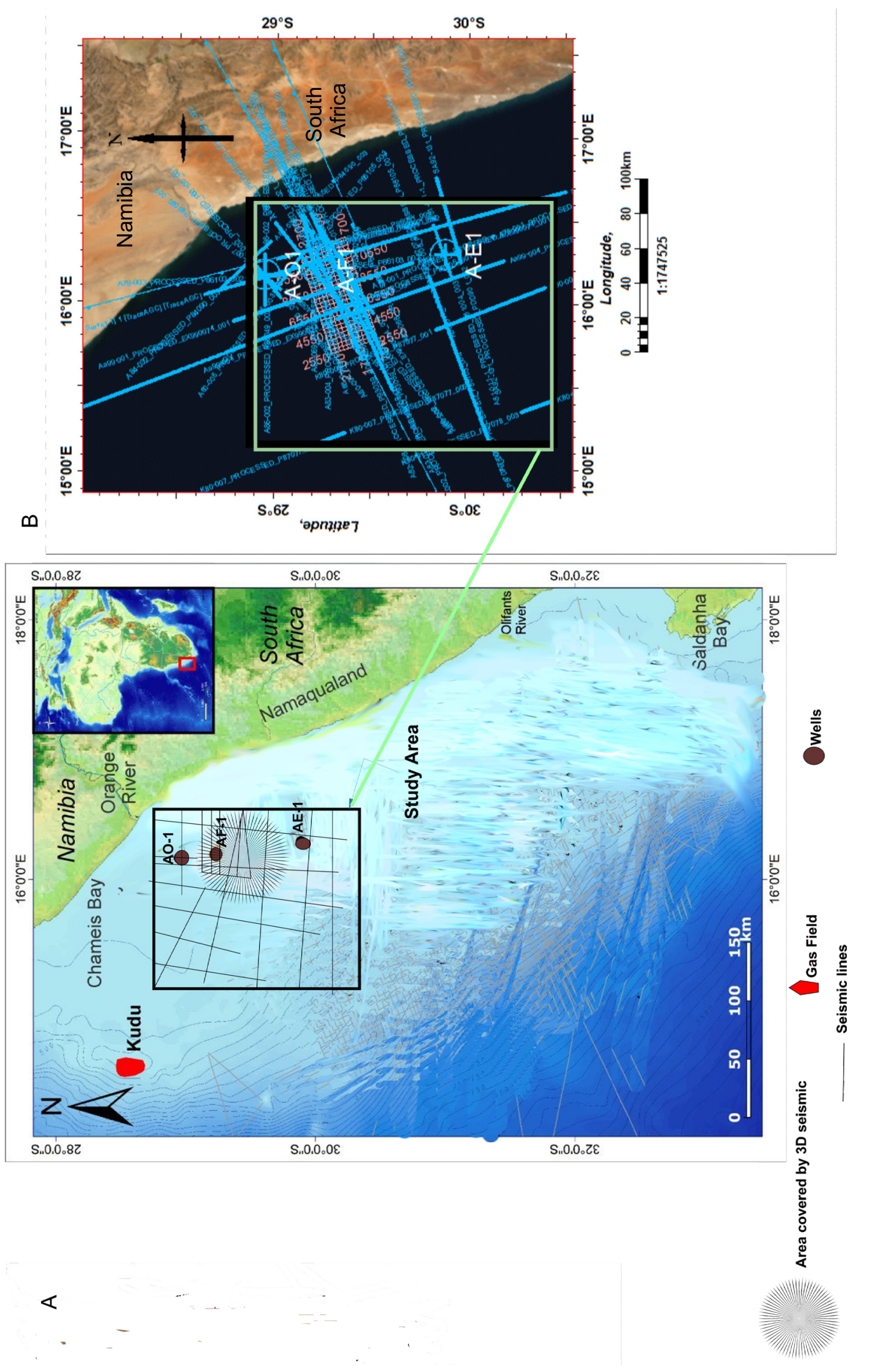

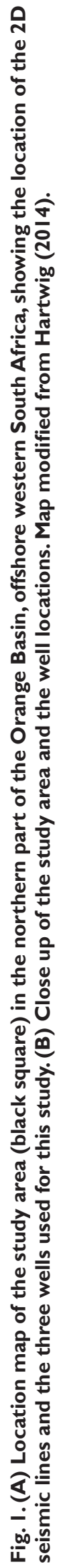




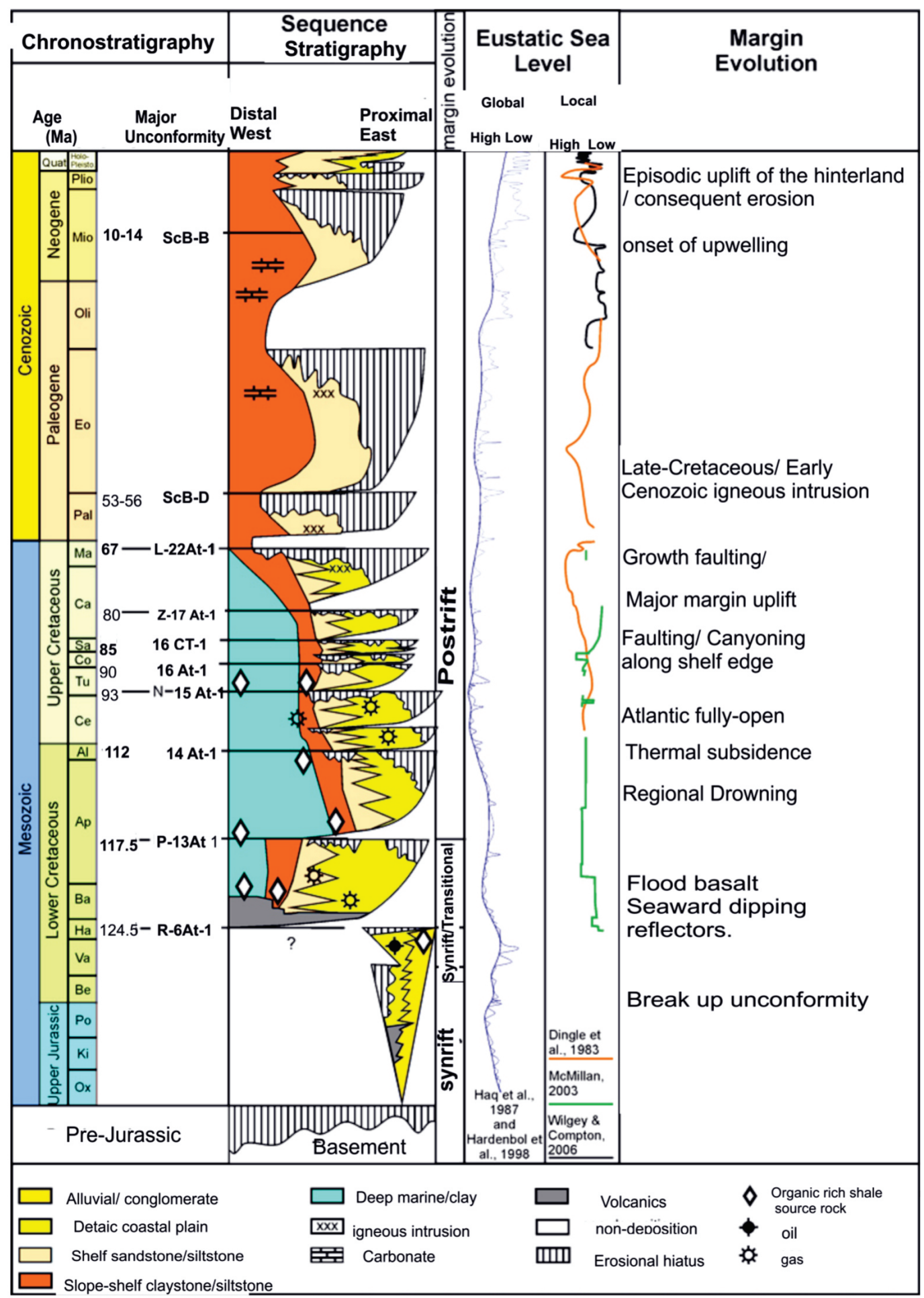

Fig. 2. (A) Generalised chronostratigraphy of the Orange Basin with the tectonic events that characterised the evolution of the western margin of South Africa (Hartwig et al., 20 I 2). Cenozoic ages after Weigelt and Uenzelmann-Neben (2004); sea level curves after Dingle et al., 1983; Haq et al., 1987; Hardenbol et al., 1998; McMillan, 2003; Wigley and Compton, 2006.

transgressions and regressions with a thickness up to 3500 m (van der Spuy, 2003; Hartwig et al., 2012). Albian and Cenomanian sandstones form the most important reservoir rocks in the basin, and depositional settings range from fluvial in the south of the basin to deltaic/ shallow marine in the north (Samakinde et al., 2021; Fadipe et al., 2011).
Towards the end of the Cretaceous, the African plate margin was tilted and uplifted as a result of magmatic underplating related to the Africa super-plume (Nyblade and Robinson, 1994), resulting in the erosion of inner shelf deposits and the subsequent deposition of a thick, prograding Campanian-Maastrichtian succession in the Orange Basin (Broad et al., 2007; 


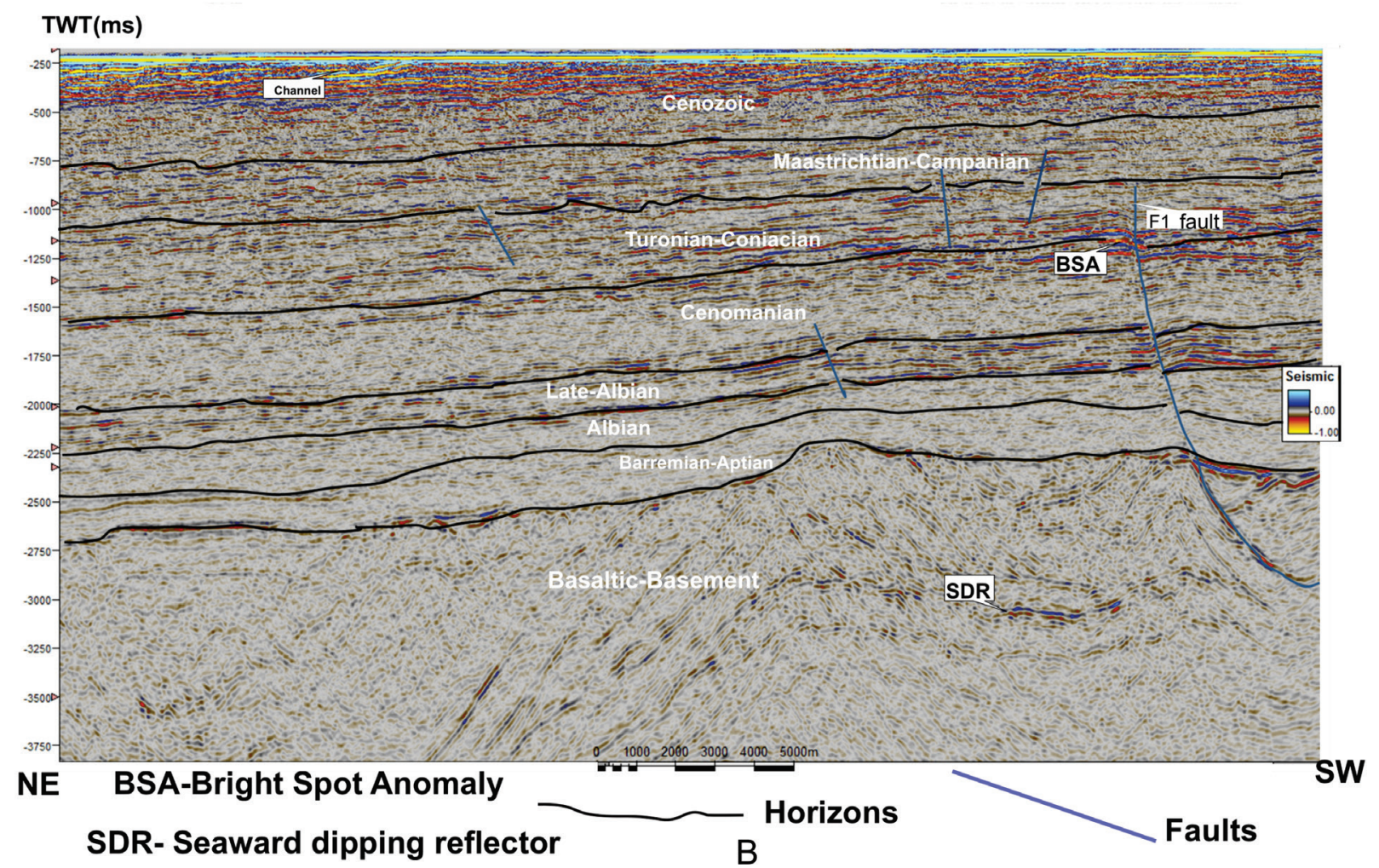

Fig. 2 (B). Seismic profile (in-line) showing the major horizons and faults mapped in the study area. Fault FI is of particular interest because of the associated bright spot anomaly (see text).

Dingle et al., 1983). Uplift is suggested to have triggered gravity-induced tectonics with widespread slumps and slides (Faulkner, 2000; Scarselli et al., 2016), and the reactivation of pre-existing growth faults and toe-thrusts in the outer basin margin (Brown et al., 1996). Cenozoic sedimentation was mainly restricted to the upper slope and was characterised by the deposition of sandy sediments including calcareous sandstones and shale-rich limestones (Gerrard and Smith, 1982).

\section{Petroleum system}

Previous studies in the Orange Basin have identified an active Barremian-Aptian source rock and, more recently, Cenomanian and Turonian source facies in addition to synrift Hauterivian shales which may have some oil potential (Aldrich et al., 2003; Adekola et al., 2012). However, the main petroleum system is sourced by Barremian - lower Aptian marine shales containing Type III OM (Petroleum Agency SA, 2006). The source rock as encountered by the DSDP 361 borehole has a thickness of up to $300 \mathrm{~m}$ with TOC as high as $25 \%$ and $\mathrm{HI}$ of $800 \mathrm{mg} \mathrm{HC} / \mathrm{g}$ (Herbin et al., 1987). The presence of an active petroleum system in deep-water parts of the Orange Basin is supported by indirect evidence on seismic profiles including the occurrence of gas chimneys and wipe-out zones, seafloor gas-escape features and flat and bright spots (Jikelo, 1999). A bright spot anomaly associated with a listric normal fault (F1) is present on a seismic profile mapped for the present study (Fig 2B).

The majority of gas shows occur in Albian sandstones (McMillan, 2003; Jungslager, 1999) whose reservoir quality has, however, been reduced in proximal parts of the basin as a result of the precipitation of quartz and illite (Samakinde et al., 2016). Hartwig (2014) showed that hydrocarbons generated from Barremian-Aptian source rocks may migrate vertically up through the overlying Cenomanian and Albian sand-rich succession until they reach Coniacian to Campanian claystones which serve as a regional seal, causing the hydrocarbons to migrate laterally.

\section{METHODOLOGY}

The following workflow describes the approach adopted for the numerical simulation study.

\section{Seismic interpretation}

Forty-two 2D seismic profiles were available for this study totalling $3537 \mathrm{~km}$ in length (Figs 1A, 1B). The profiles were selected based on their orientations in strike and dip directions in order to create a grid (see Fig 1A) which was integrated with a 3D seismic cube covering approximately $750 \mathrm{sq}$. $\mathrm{km}$ around wells AO1, AE-1 and AF-1 (Figs 1A, 1B). The SEG-Y seismic sections were loaded together with well data (sonic 


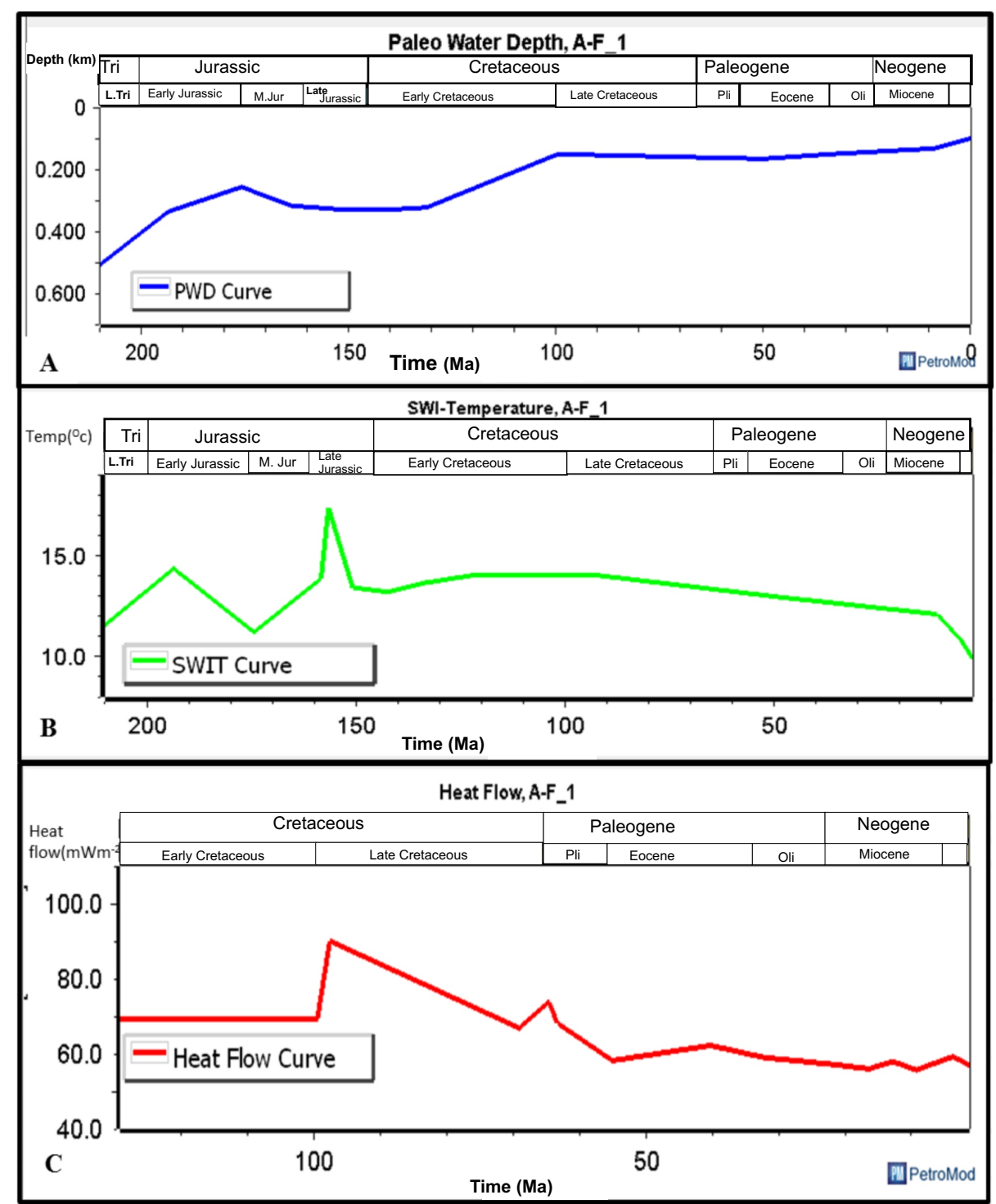

Fig. 3. Model boundary conditions through time. (a) palaeo water depth (PWD); (b) sediment water interface temperature (SWIT); and (c) heat flow (HF).

and density logs, formation tops and checkshot data) into Petrel 2018 for processing and interpretation. Mapping of stratigraphic horizons and faults within the chronostratigraphic framework (Fig. 2A) was preceded by a mis-tie analysis of the $2 \mathrm{D}$ seismic data in order to match the amplitudes of the various vintages of data with the 3D seismic volume.

Seven major stratigraphic horizons (Barremian Aptian, Albian, Late Albian, Cenomanian, Turonian, Campanian-Maastrichtian and Cenozoic) were mapped in the study area. These horizons were gridded into surfaces to create two-way-time maps, followed by the construction of a fault model for the study area. A total of 42 faults (mostly normal and listric faults) offsetting the stratigraphic horizons were identified. Listric fault F1 was of particular interest because of the associated bright spot (Fig 2B). Samakinde et al. (2020) reported the attenuation of seismic frequencies around the bright spot which indicate the presence of gas-saturated sediments in close proximity to the fault.

\section{Velocity modelling for depth conversion}

Sonic and density log data from wells AO-1, AF-1 and AE-1 were calibrated with checkshot data to generate velocity and reflection-coefficient logs. A synthetic seismogram was estimated using the Ricker-zero phase wavelet from this process, followed by bulk shifting to balance the amplitudes of the synthetic seismogram and the seismic data. A velocity model was then constructed using Petrel 2018; interval velocity logs, TWT maps (estimated from the process described above) and formation tops (time and depth attributes) for the three wells studied were used as inputs.

Model building was based on the formula $\mathrm{V}=\mathrm{V}_{0}$ $+\mathrm{K}^{*} \mathrm{Z}$, where $\mathrm{V}_{0}$ represent the interval velocity of the stratigraphic interval; and $\mathrm{K}$ represents the gradient of velocity increase with depth, $\mathrm{Z}$, derived from establishing the time-depth relationship between the seismic data and the wells.

A velocity model was created, and the TWT maps were converted into depth maps. These maps 
Table I. Facies assignment table showing the relative abundance of various lithologies used for the model. $\mathrm{Sh}$, shale; Si, siltstones; Ss, sandstones. The TOC content of the source rocks is assigned. Note: only BarremianAptian source rocks were modelled for the study.

\begin{tabular}{|l|l|l|l|l|}
\hline & & & & \\
\hline Geological Ages & PSE & $\begin{array}{l}\text { Lithology } \\
\text { Values }\end{array}$ & $\begin{array}{l}\text { TOC Value } \\
\mathbf{( \% )}\end{array}$ & HI (mg/HC) \\
\hline Cenozoic & & Sh25Ss70Si5 & & \\
\hline Maastrichtian & & Sh25Ss70Si5 & & \\
\hline Turonian & & Sh50Ss35Si15 & 3 & \\
\hline Cenomanian & Reservoir & Si70Ss25Sh5 & & \\
\hline Late Albian & Seal & Sh70Ss25Si5 & & \\
\hline Albian & Reservoir & Sh50Ss50 & & \\
\hline Barremian/Aptian & & Sh50Si30Ss20 & 0.6 & 290 \\
\hline
\end{tabular}

were exported into Petromod to initiate the model of hydrocarbon generation and migration.

\section{Data inputs and boundary conditions}

Average values of the total organic carbon (TOC) content, Hydrogen Index (HI) and temperature data for the Barremian-Aptian source rock, obtained from geochemical reports of the three wells, were used as inputs for the 3D model. Lithologies were assigned to the depth maps based on petrographic reports and lithology logs (Table 1; see below), and lithological properties were in addition assigned based on existing models in Petromod. The Sekiguchi model (1977) was used for thermal conductivity; the Waples model (2004) for radiogenic heat production, and Athy's law (1930) for porosity prediction. In addition, the model described by Schneider et al. (1996) was used for the prediction of chemical compaction, while a multipoint model was used to predict permeability and a bilinear equation was used to predict the sealing properties of the rocks.

A fault model was constructed from the mapping of regional faults which offset the stratigraphy as planes of discontinuity on the seismic sections. The hydraulic properties of these faults were assigned based on their evolution as either syn-rift or post-rift; syn-rift faults were considered to be open, and post rift faults were considered to be closed for the numerical modelling process.

Boundary conditions were based on the regional geology of the study area and the latitude, which was set at $33^{\circ} \mathrm{S}$ in the simulator. The latitude influences the Sediment Water Interface Temperature (SWIT) which was estimated through time using the Wrygla model (1989) (Fig. 3A). Average palaeo-water depth (PWD) values were derived from well completion reports and constrained by palaeontological studies (Fig. 3B).

The McKenzie heat flow model (1978) was used to reconstruct the thermal history of the Orange Basin (Fig. 3C). Varying heatflow values were assigned to the different periods of margin uplift characterising basin evolution. A heatflow value of $70 \mathrm{mWm}^{-2}$ was assigned for the Late Jurassic - Early Cretaceous rift and drift phase (c.f. Kounov et al., 2009). A value of $90 \mathrm{mWm}^{-2}$ was considered for the Cenomanian during which there was uplift of the Southern Africa Plateau (Braun et al., 2014). A value of $72 \mathrm{mWm}^{-2}$ represented the phase of Late Cretaceous uplift of the African Plate (Nyblade and Robinson, 1994); and $62 \mathrm{mWm}^{-2}$ for Miocene uplift of the South African continental margin (Jung et al., 2014). These values were adopted after several iterations during the simulation process to obtain a good fit between the measured and the modelled paleotemperature data. A present-day heatflow value of 52 $\mathrm{mWm}^{-2}$ was assigned to the model based on borehole temperatures (Goutorbe et al., 2008).

In general, the heat flow history of the SW African margin was influenced by magmatic underplating which caused lithospheric thinning by up to $30 \%$ during the early rift period leading to increased subsidence (Hirsch et al., 2010). This was followed by periods of varying heat flow accompanying episodes of uplift during the margin evolution; high heat flows were prominent during periods of erosion of the inner shelf at around $74 \mathrm{Ma}$ and $14 \mathrm{Ma}$ (Kounov et al., 2009).

\section{Lithology mixing}

Lithological assignment was a key part of the 3D petroleum systems modelling workflow. Table 1 shows the lithological assignments used: lithologies were shale (Sh), siltstone ( $\mathrm{Si}$ ) and sandstone (S), and relative abundances were assigned for each stratigraphic surface generated from the velocity modelling process. The stratigraphic surfaces used to perform lithology mixing were: Barremian - Aptian (source rock), Albian (reservoir), Late Albian (seal), Cenomanian (reservoir), Turonian (source rock - not simulated), Maastrichtian, and Cenozoic. These stratigraphic surfaces served as model inputs for the initial static geological model. Fig. 4 shows the static 3D lithology model constructed for 
Table 2.Thermal and organic maturation data for the three wells used to calibrate the 3D model.

\begin{tabular}{|c|c|c|c|c|}
\hline \multicolumn{5}{|l|}{ AE-1 } \\
\hline Depth(m) & VR(\%) & Tmax & Depth(m) & Temperature $\left({ }^{\circ} \mathrm{C}\right)$ \\
\hline 1900 & 0.68 & 438 & 2000 & 72 \\
\hline 2200 & 0.8 & 446 & 2500 & 90 \\
\hline 2400 & 0.74 & 444 & 3000 & 108 \\
\hline 2600 & 0.75 & 445 & 3500 & 126 \\
\hline 2800 & 0.82 & 452 & 4000 & 144 \\
\hline 3000 & 0.9 & 454 & & \\
\hline 3200 & 1 & 464 & & \\
\hline 3400 & 1.35 & 470 & & \\
\hline 3600 & 1.4 & 475 & & \\
\hline 3800 & 1.5 & 485 & & \\
\hline \multicolumn{5}{|l|}{4000} \\
\hline \multicolumn{5}{|l|}{ AF-1 } \\
\hline $\operatorname{Depth}(\mathrm{m})$ & VR(\%) & Tmax & Depth(m) & Temperature $\left({ }^{\circ} \mathrm{C}\right)$ \\
\hline 1200 & 0.39 & 425 & 700 & 60 \\
\hline 1500 & 0.5 & 430 & 900 & 72 \\
\hline 1600 & 0.42 & 428 & 1300 & 81 \\
\hline 1700 & 0.5 & 430 & 2000 & 92 \\
\hline 1780 & 0.8 & 450 & 3000 & 105 \\
\hline 1900 & 0.59 & 455 & & \\
\hline 3000 & 1.3 & 465 & & \\
\hline 3100 & 0.9 & 458 & & \\
\hline \multicolumn{5}{|l|}{ AO-1 } \\
\hline $\operatorname{Depth}(\mathrm{m})$ & VR (\%) & Tmax & Depth(m) & Temperature $\left({ }^{\circ} \mathrm{C}\right)$ \\
\hline 1050 & 0.3 & 438 & 2000 & 54.6 \\
\hline 1100 & 0.32 & 446 & 2500 & 67.6 \\
\hline 1200 & 0.39 & 444 & 3000 & 81.9 \\
\hline 1250 & 0.38 & 445 & 3500 & 95.2 \\
\hline 1300 & 0.56 & 452 & 4000 & 108 \\
\hline 1400 & 0.5 & 454 & & \\
\hline 1590 & 0.59 & 464 & & \\
\hline 1900 & 0.56 & 470 & & \\
\hline 2000 & 0.57 & 475 & & \\
\hline 2050 & 0.63 & 485 & & \\
\hline \multicolumn{5}{|l|}{4000} \\
\hline & & & & \\
\hline & & & & \\
\hline
\end{tabular}

the study area and the distribution of the three wells used for calibration; labels highlight the distribution of source, reservoir and caprocks.

\section{Calibration data}

Vitrinite reflectance (VR) data together with RockEval $\mathrm{T}_{\max }$ and borehole temperature data were used for calibration (Table 2). Measured VR data obtained from the geochemistry reports were validated and compared with those obtained by calculation using the empirical formula $\% \mathrm{R}_{\mathrm{o}}$ (calculated) $=0.0180 \times \mathrm{T} \mathrm{T}_{\max }{ }^{-}$ 7.16 applicable to Types II and III kerogen (Peters et al., 2006). Measured VR data in general compared well with calculated data.

For the temperature model, a geothermal gradient of $3.5^{\circ} \mathrm{C} / 100 \mathrm{~m}$ was assumed and calibrated with downhole temperature data from the three wells.

\section{Erosion}

In the model, erosional events were linked to various episodes of uplift that characterised the evolution of the SW African continental margin. Previous studies (Hirsch et al., 2010; Kuhlmann et al., 2010) suggested that Late Cretaceous and Miocene erosional phases were pervasive in the Orange Basin. However, Cenomanian erosion (Braun et al., 2014) may have been less significant in the basin. Thus, an eroded thickness of $360 \mathrm{~m}$ spanning a period of $8 \mathrm{Ma}$ (from $100 \mathrm{Ma}$ to $92 \mathrm{Ma}$ ), which was initially included in the model, was excluded because no significant changes in the model were observed. However, Cenomanian erosion in the hinterland may have resulted in the transport of sediments into the Orange Basin and contributed to significant offshore progradation as documented by Dingle et al. (1983).

After several iterations during the simulation process, values of $450 \mathrm{~m}$ for the thickness of eroded sediments in the Late Cretaceous - Early Cenozoic (65-40 Ma), and $400 \mathrm{~m}$ for the Miocene (20 to $14 \mathrm{Ma}$ ) were factored into the model. These values provide the best fit for the calibration of modelled VR with measured VR. The values differ from those adopted by Campher (2009), who estimated $421 \mathrm{~m}$ of eroded sediments for the Miocene and $961 \mathrm{~m}$ for the entire Cretaceous. They are also at variance with Hartwig (2014) who proposed an eroded thickness of $360 \mathrm{~m}$ 


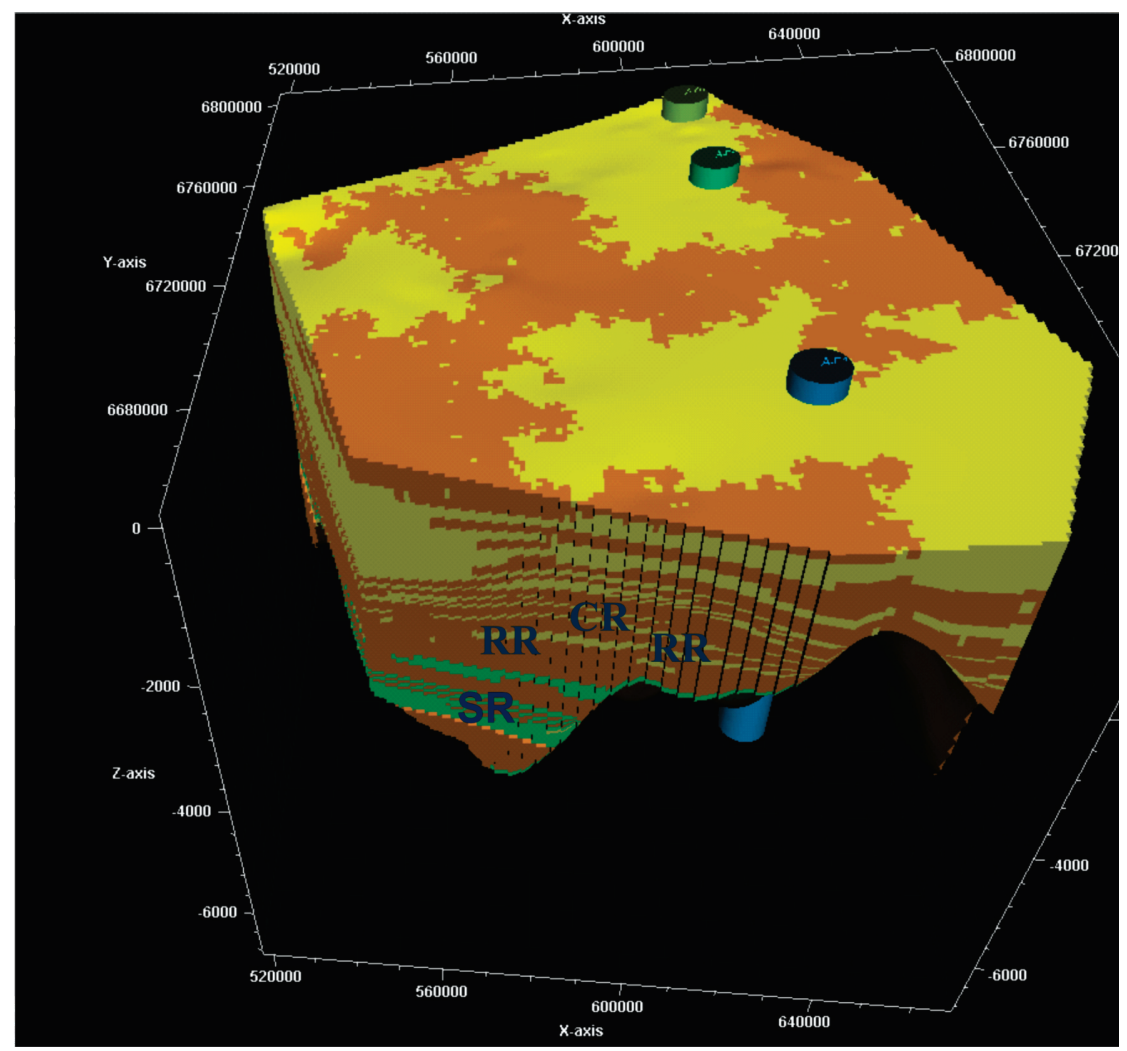

Fig. 4.3D facies model of the study area showing the source rock (SR), reservoir rock (RR) and cap rock (CR) distributions, and the locations of the three wells studied. The area of the figure is shown by the black box in Fig. IA.

for the Oligocene and Miocene sequence (based on Wigley and Compton, 2006), and a total of $1000 \mathrm{~m}$ for the entire Cretaceous. Note however that both of the above studies were carried out for the southern part of the Orange Basin and that the extrapolation of erosion estimates can only be tentative.

\section{Hydrocarbon generation}

\section{and migration modelling.}

Hydrocarbon generation from the Barremian-Aptian source rocks was modelled using a Hydrogen Index of $290 \mathrm{mg} \mathrm{HC} / \mathrm{gTOC}$ and a TOC of $0.6 \%$ based on the geochemical well reports. Reaction kinetics from Pepper and Corvi (1995) for Type III organic matter were used; this was applicable to the source rock in the study area (Jungslager, 1999).

For hydrocarbon migration modelling, a Hybrid Flow Path Darcy model was used (IES, 2007). The model combines buoyancy-driven migration and Darcy flow, and integrates relevant physical parameters such as pressure, volume and temperature (Hantschel et al., 2000). The model follows a flow-path tracing method and identifies lithologies with more than $30 \%$ porosity and a pre-defined permeability value of $10^{-2}$ $\mathrm{mD}$ as carrier beds. In the absence of such lithologies, it switches to bed surface geometry as the flow-path tracing method (Hantschel et al., 2000). This is important for defining hydrocarbon drainage areas, the analysis of spill points and the assessment of migration along faults.

\section{RESULTS}

\section{D Temperature models}

Profiles versus depth of modelled temperatures compared with measured temperatures for wells AO-1, AF-1 and AE-1 are presented in Figs 5A-C. In general, there is a good fit between measured and modelled downhole temperatures. There is a minor discrepancy at $2 \mathrm{~km}$ depth in well AO-1 where the measured temperature $\left(50^{\circ} \mathrm{C}\right)$ is less than the modelled temperature $\left(60^{\circ} \mathrm{C}\right)$ (Fig. 5A). The BarremianAptian interval is at a depth of $4 \mathrm{~km}$ in this well. Its temperature is $110^{\circ} \mathrm{C}$ at this location, $120^{\circ} \mathrm{C}$ at 3.5 $\mathrm{km}$ in well AF-1, and $140^{\circ} \mathrm{C}$ at $4.0 \mathrm{~km}$ in well AE-1, indicating a gradual increase in temperature from north to south in the study area.

Variations in subsurface temperatures in a basin may be due to a number of factors including lateral variations in lithospheric thickness (Hirsch et al., 2007), rift related exhumation (Hart et al., 2017), and the presence of a thick overburden which acts as a thermal blanket (Slagstad et al., 2008). In this study, the higher downhole temperatures recorded in wells AF-1 and AE-1 (Figs 5B and C) are likely to have been caused by the blanketing effect of the relatively thick 

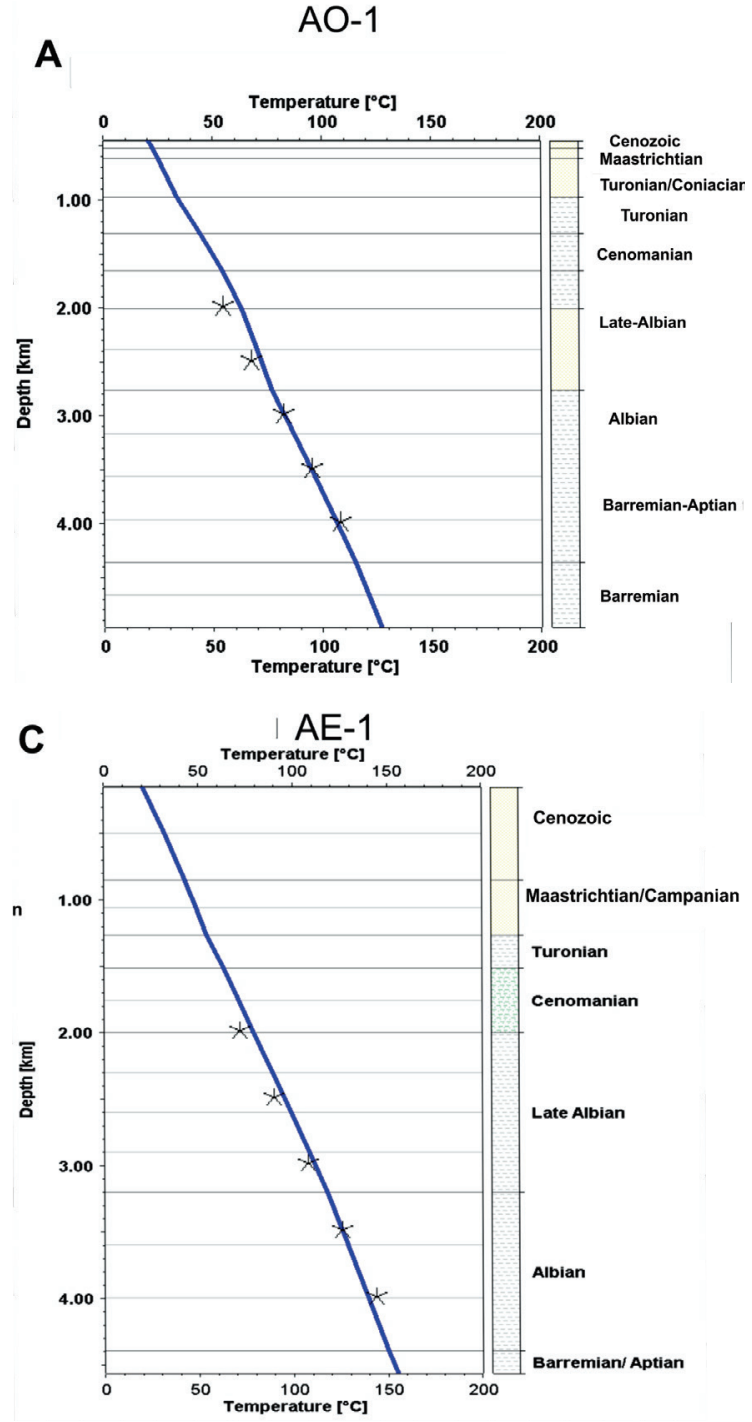

silt-rich succession at these locations compared to that in well AO-1 in the north of the study area.

\section{D Vitrinite reflectance models}

Profiles of modelled vitrinite reflectance (VR) versus depth for the three wells calibrated with measured data are presented in Figs 6A-C. In general, there is a good fit between modelled and measured data although some discrepancies occur. Thus in well AO-1 in the north of the study area, the measured VR which is $0.32 \% \mathrm{R}_{\mathrm{o}}$ at $1.1 \mathrm{~km}$ depth within the Turonian-Coniacian succession is less than the modelled value of $0.36 \% \mathrm{R}_{0}$ (Fig. 6A, blue circle). Note that in well AE-1 to the south, there are no measured VR values to calibrate the modelled VR for the Turonian.

In well AO-1, at $1.3 \mathrm{~km}$ depth in the CenomanianTuronian, the measured VR is $0.6 \% \mathrm{R}_{\mathrm{o}}$ (Fig. 6A, red circle) and is higher than the modelled VR of $0.5 \% \mathrm{R}$. Similarly, in well AF-1 (Fig. 6B) the measured and modelled VR values are 0.7 and $0.51 \% \mathrm{R}_{\mathrm{o}}$ respectively at $1.1 \mathrm{~km}$ depth for the Cenomanian-Turonian. Also, the measured VR is $0.7 \% \mathrm{R}$ at $2.1 \mathrm{~km}$ depth within

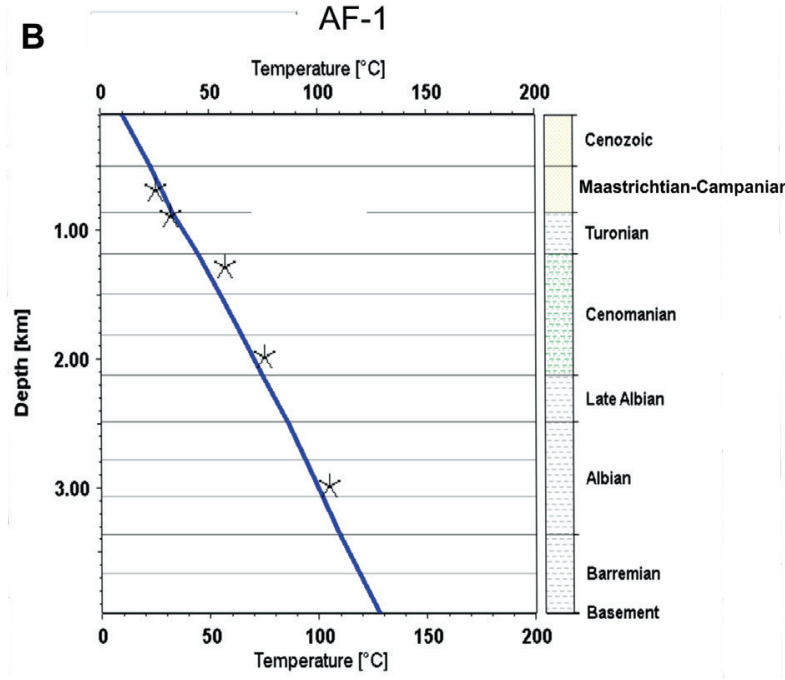

Fig. 5A-C. ID downhole temperature models for wells AO-I (A),AF-I(B) and AE-I (C) along a north -south transect. The solid line is the modelled temperature while the stars show measured temperature values. the Cenomanian and is higher than the modelled VR of $0.6 \% \mathrm{R}_{\mathrm{o}}$ (red circles in Fig. $6 \mathrm{C}$ ).

The occurrence of higher measured VR values compared to modelled values for the Cenomanian interval is probably due to an increase in heatflow associated with high sedimentation rates and the progradation of the Cenomanian sedimentary succession (Dingle et al., 1983). Relatively high sedimentation rates and consequent compaction in extensional basins account for up to $30 \%$ of heat absorption within the sedimentary sequence compared to $10 \%$ absorption associated with lower rates of sedimentation (Lucazeau and Le Douaran, 1985).

\section{D Temperature model}

Maps showing modelled variations in maximum temperature for the Barremian-Aptian source rock interval are shown in Figs 7A and B for the present day (0 Ma) and the Late Cretaceous (65 Ma), respectively. At the present day (Fig. 7A), the interval has a modelled maximum temperature of $110^{\circ} \mathrm{C}$ around well AO- $1,120^{\circ} \mathrm{C}$ around well $\mathrm{AF}-1$, and $140^{\circ} \mathrm{C}$ around 
A.

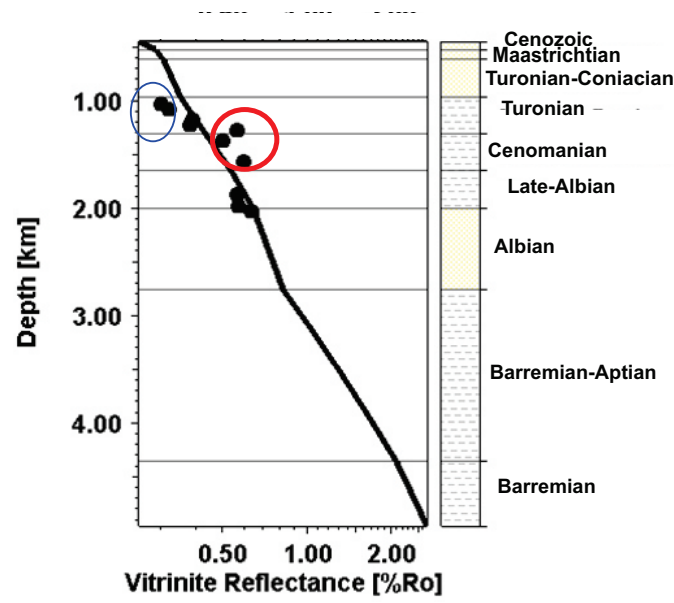

Fig. 6 A-C. ID Vitrinite reflectance models for wells AO-I (A),AF-I (B) and AE-I (C). The solid line is the modelled VR while the dots show measured VR values. Red circles indicate higher measured VR values compared with modelled $V R$, while the blue circle (Fig. 6A) indicates lower measured VR compared to modelled VR.

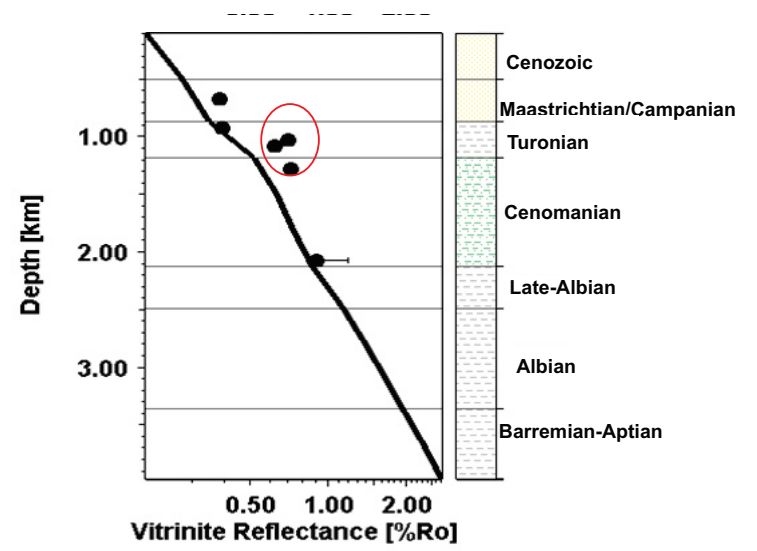

B.

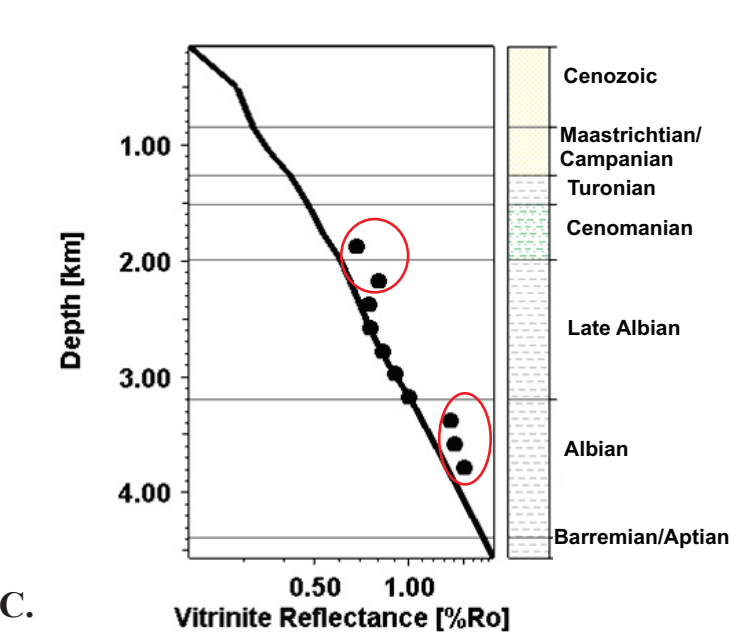

central $\left(\% \mathrm{R}_{\mathrm{o}}=0.7 \sim 1\right)$ and southern $\left(\% \mathrm{R}_{\mathrm{o}}=0.85 \sim 1.1\right)$ parts of the study area, and lower thermal maturity to the north $\left(\% \mathrm{R}_{\mathrm{or}}=0.4 \sim 0.65\right)$. The map indicates that the Barremian-Aptian interval around well AE-1 (in the south of the study area) is in the gas generation window $\left(\% \mathrm{R}_{\mathrm{o}} \sim 1.0\right)$, in the oil generation window $\left(\% \mathrm{R}_{\mathrm{or}} \sim 0.8\right)$ at well AF-1 in the centre, and is thermally immature $\left(\% \mathrm{R}_{\mathrm{o}} \sim 0.5\right)$ at well AO-1 in the north. Fig. $8 \mathrm{~B}$ shows modelled VR variations for the Barremian-Aptian interval at $65 \mathrm{Ma}$, and indicates that the estimated VR was $0.7 \sim 0.9 \% \mathrm{R}_{\mathrm{o}}$ in the distal (western) portion of the study area.

A NE-SW profile (Fig. 8C) showing the presentday thermal maturity within the Barremian-Aptian interval shows a VR increase from $\sim 0.53 \% \mathrm{R}_{\mathrm{o}}$ at $2 \mathrm{~km}$ depth in the north of the study area to $\sim 0.82 \% \mathrm{R}_{\mathrm{o}}$ in the south (Fig. 8C). Thus in general, the modelled thermal maturity increases from north to south in the study area.

\section{Hydrocarbon generation model}

The transformation ratio (TR) map for the BarremianAptian source rock interval at the present day (Fig. 9A) shows that the TR is highest in the central part of the (Fig. 8A) indicates higher thermal maturities in the 

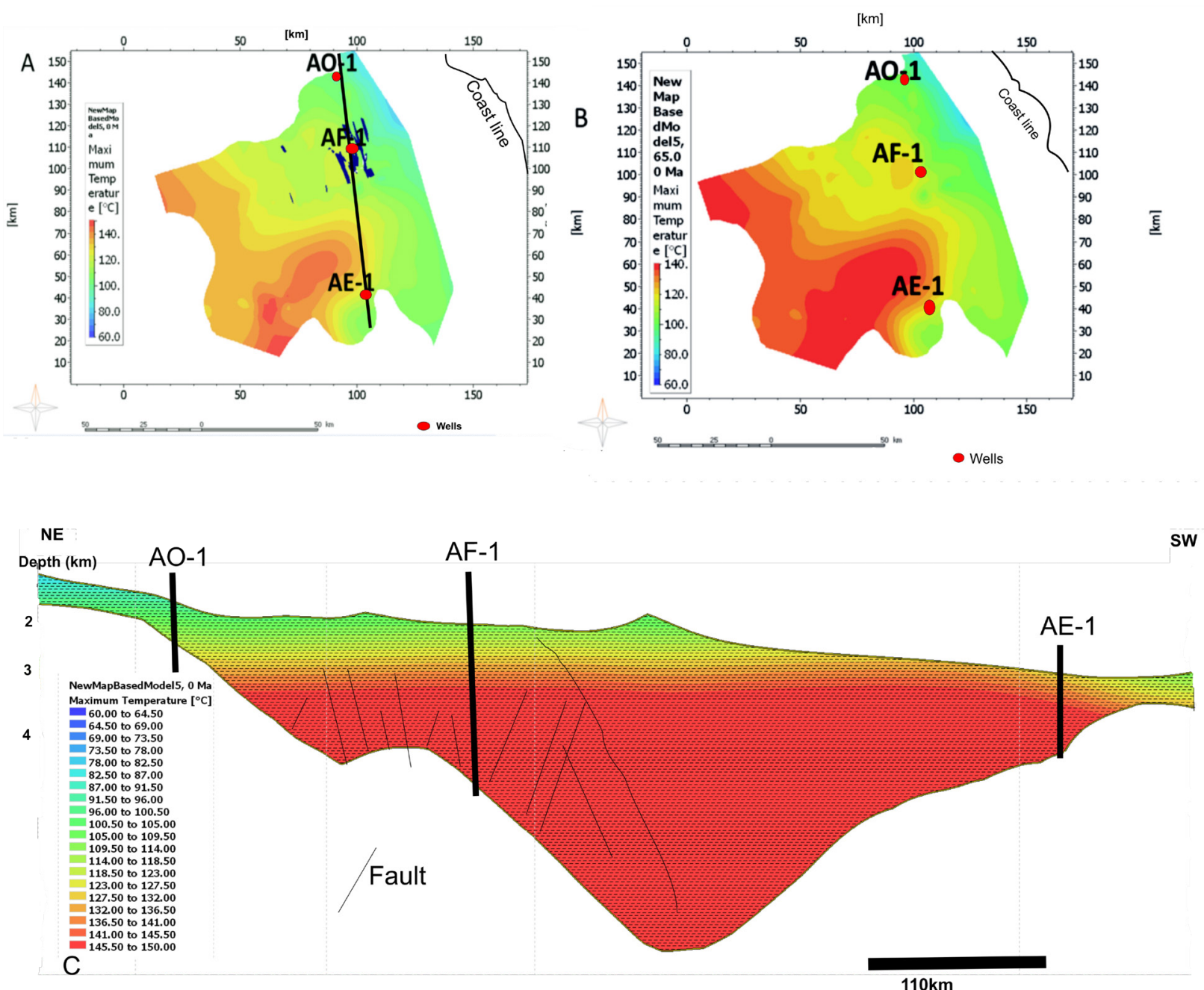

Fig. 7A-C.Temperature variation models for the Barremian-Aptian unit $(A)$ at the present day $(0 \mathrm{Ma})$, and at 65 Ma (B).A present-day downhole temperature cross-section of the Barremian-Aptian unit is shown below in (C). The blue polygons on the present-day map $(A)$ are faults mapped within the study area and incorporated into the 3D model (150 km by $150 \mathrm{~km})$.

study area and is $\sim 80 \%$ around well AF- 1 . The ratio is $\sim 5 \%$ at well AO- 1 in the north of the study area, and $\sim 60 \%$ around well AE-1 in the south (Fig. 9A).

Comparison of the TR model with the 1D TR models for the well locations (Figs 9B, 9C, 9D) tends to validate the results of the hydrocarbon generation model. The TR model for wells AF-1 (Fig. 9C) and AO-1 (Fig. 9D) shows that hydrocarbon generation started as early as the late Aptian-Albian at a depth of $3000 \mathrm{~m}$ (late Aptian) for well AF-1 (in the centre of the study area), and at a depth of $3400 \mathrm{~m}$ (Early Albian) for well AE-1 (in the south) and continues to the present day (Figs 9C and D). However, the source rock in well AO-1 in the north of the study area (Fig. 9B) has not reached sufficient thermal maturity for hydrocarbon generation.

\section{Timing of hydrocarbon generation and volumetrics}

The volume of hydrocarbons generated from a source rock is a product of the area, the source rock thickness, the hydrocarbon yield (a function of the kerogen type; in this case Type III), and the expulsion efficiency. The simulator takes into consideration the area covered by the model $(150 \mathrm{~km} \mathrm{X} 150 \mathrm{~km})$, the thickness of the Barremian - Aptian interval in which the source rock occurs, and the type of kerogen in the source rock units.

In this study, the source rock expulsion efficiency was $77 \%$; this represents the ratio of the volume of hydrocarbons expelled from the source rock per $\mathrm{m}^{3}$ after generation had occurred. The value is often relatively high for a gas-prone source rock (up to 80\%: Magara, 1980) since gas expulsion is driven by a number of forces including buoyancy, molecular diffusion and thermal expansion (Pang et al., 2006). In this study, gas is the main hydrocarbon modelled to have been expelled from the Barremian - Aptian source rock and an expulsion efficiency of $77 \%$ is therefore appropriate. The model indicates that within the study area, the Barremian - Aptian source rock has contributed 42,980 million tons of gas and 3850 million tons of oil, representing $91.8 \%$ and 

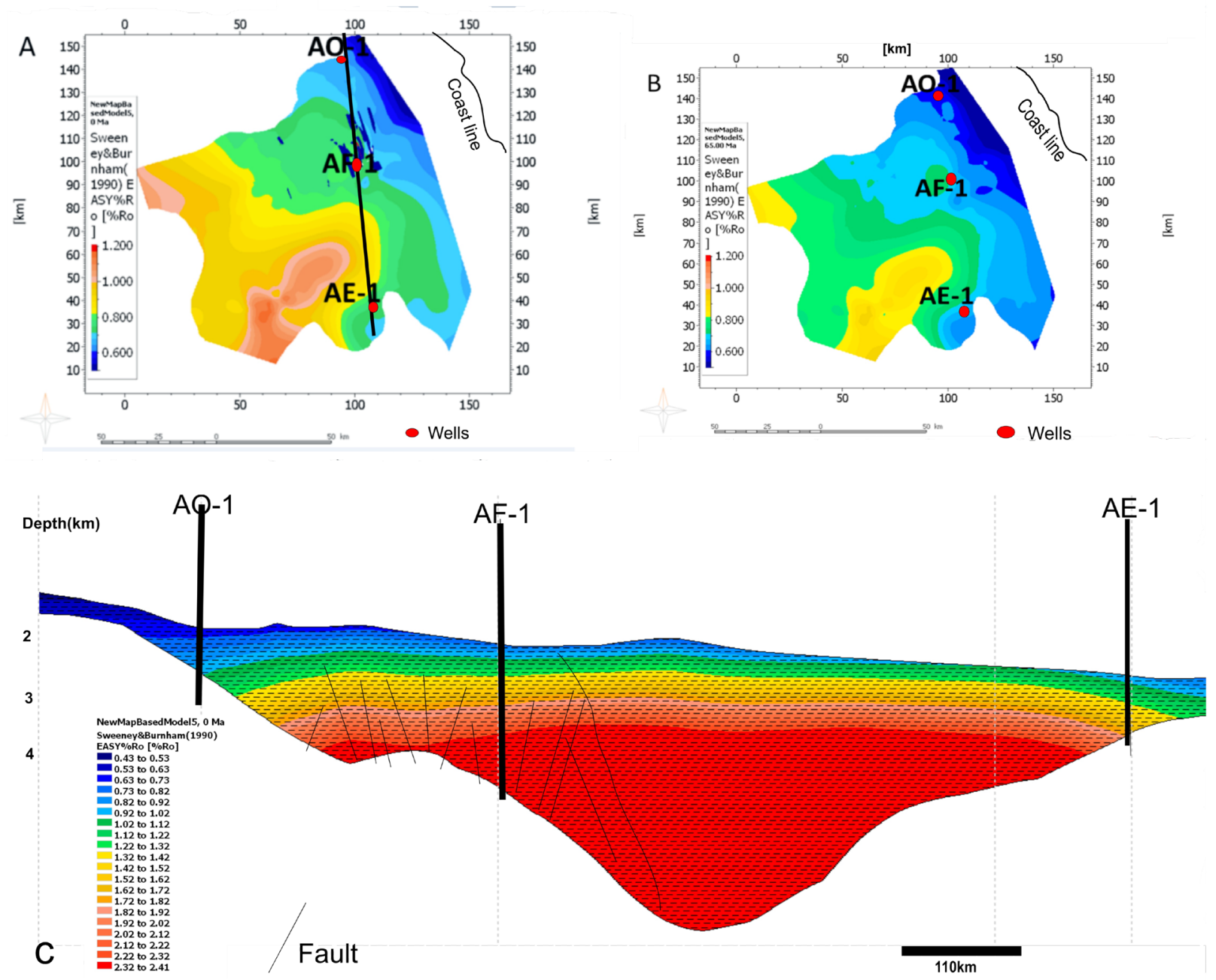

Fig. 8.Vitrinite reflectance models at the present day (A) and at $65 \mathrm{Ma}(\mathrm{B})$; a present-day vitrinite reflectance cross-section for the Barremian-Aptian is shown in (C). The blue polygons on the present-day map are faults mapped within the study area and incorporated into the 3D model. The western and central parts of the study area are thermally mature while the northern section is immature.

$8.2 \%$ of the hydrocarbons generated respectively (Fig. 10A). However, these volumes are necessarily approximations because the source rock distribution and thickness across the study area was not known. The simulator based the volumetric estimates on the relative abundance of shales to other rock units within the Barremian-Aptian sequence, which is $50 \%$ (see Table 1). The $50 \%$ estimate was based on information from petrological reports, well completion reports and logs analysis of the three wells in the study area.

The model also indicates that hydrocarbon generation and accumulation within the source pod started at about $117 \mathrm{Ma}$ (Fig. 10B), and by $110 \mathrm{Ma}$ the accumulation of hydrocarbons in the source rock was sufficient for expulsion to occur. Accumulation of generated hydrocarbons peaked at the beginning of the Late Cretaceous (Cenomanian), while expulsion reached a peak in the Late Cretaceous - earliest Cenozoic (Fig. 10B). Hydrocarbon generation and expulsion continued at a constant rate from the start of the Cenozoic and have persisted to the present day.
Hydrocarbon migration, 3D fault model and fault control on migration pathways

Potential reservoir units were identified and assigned within the Albian and Cenomanian successions (Table 1). Migration modelling suggests that oil and gas migration has taken place within the Albian carrier sandstones, as shown in the map in Fig. 11A. The map shows that oil (green) has in general migrated to the west of the study area, while gas (red) appears to be more randomly located in the Albian sandstones. Cenomanian sandstones also serve as a carrier unit for relatively random gas migration (Fig. 11B). A modelled north-south cross-section (Fig.11C) suggests that oil migration within the Albian units, possibly aided by strong hydrodynamic conditions, is towards the south of the study area.

A 3D fault model for an area measuring $150 \mathrm{~km} \mathrm{X}$ $150 \mathrm{~km}$ (Fig. 12) was constructed by mapping major faults which offset more than one stratigraphic surface. Forty-two faults were mapped from the seismic data and were used to construct the model. Of these faults, 


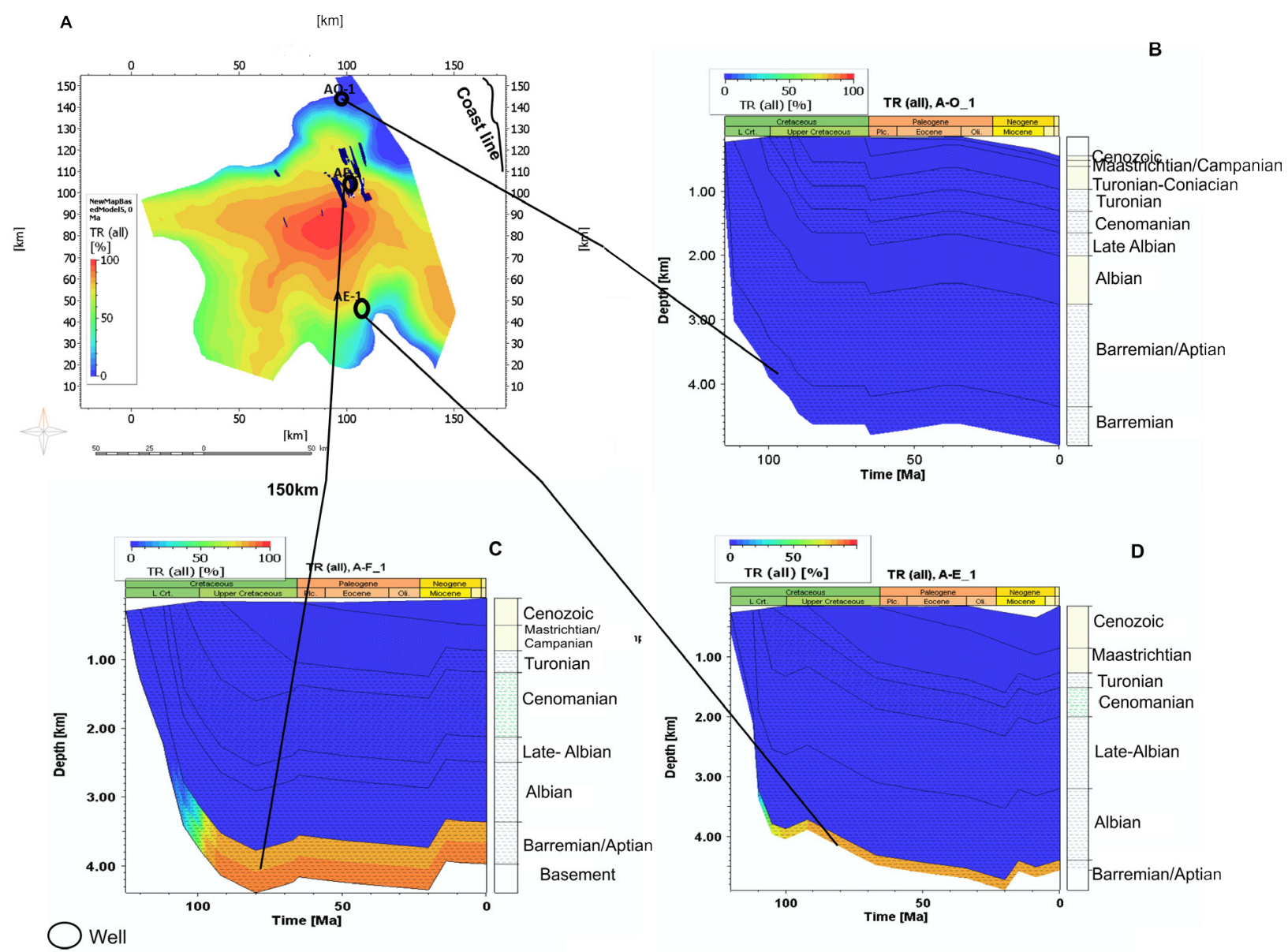

Fig. 9. Transformation ratio map of the source rock interval at the present day (A); and ID burial history plots showing the transformation ratio of the source rock at wells AO-I (B), AF-I (C) and AE-I (D) in the north, centre and south of the study area respectively.

the reactivated listric fault (F1), trending NNW-SSE, was of particular interest owing to a nearby bright spot anomaly (Fig 2B). The last increments of fault activity were dated in relative terms based on their geometry and the sedimentary sequences they offset. As no data was available with which to assign shale gouge ratios, the faults were defined as hydraulically "open" if they were active during synrift deposition, or "closed" (i.e., sealing) if they were active after rifting had ceased (Table 3). The fault model suggests that fault F1 was $100 \%$ gas saturated around $93 \mathrm{Ma}$ (Fig. 13A) but gas saturation declined to around $15 \%$ by $65 \mathrm{Ma}$ (Fig. 13B). This suggests the occurrence of a breakthrough path along the fault plane which resulted in migration of previously trapped gas to other parts of the basin. The decline in the gas saturation between $93 \mathrm{Ma}$ and $65 \mathrm{Ma}$ was probably due to the reactivation of the fault related to uplift of the South Africa (deVera et al., 2010).

To test a different migration scenario, the hydraulic properties of the faults were reversed so that synrift faults were "closed" (sealing) and post-rift faults were "open". The results were no different from the earlier scenario, thus indicating the viability of the model (Fig. 14).

\section{DISCUSSION}

\section{Heat flow}

The heat flow model in Fig. 3 proposes a present-day heat flow value of $52 \mathrm{mWm}^{-2}$. A similar value was used by Hartwig (2014) for the southern Orange Basin, but Campher (2009) proposed a heatflow of $61 \mathrm{mWm}^{-2}$ for the central part of the basin. This variation is attributed to varying thermal subsidence due to a combination of differential stretching and magmatic underplating across the continental margin (van Wees et al., 2009). Hirsch et al. (2007) suggested that non-uniform stretching of a high density and high velocity body in the lower crust resulted in magmatic underplating of the southern African continental margin.

The rifting (Late Jurassic - Early Cretaceous) heat flow used in the model is $70 \mathrm{mWm}^{-2}$. Anomalies of $90 \mathrm{mWm}^{-2}, 76 \mathrm{mWm}^{-2}$ and $62 \mathrm{mWm}^{-2}$ in the Cenomanian, Maastrichtian-Campanian and Miocene (Fig. 3C) correspond to uplift events on the South Africa margin. Heat flow from the lower crust and the variable thermal conductivity of the strata units control the geothermal gradient and influence downhole temperatures. The geothermal gradient of $3.5^{\circ} \mathrm{C} / 100$ 
Fig. 10. Hydrocarbon generation volumetrics at the present day $(A)$, and the timing of hydrocarbon generation, accumulation and expulsion (B). Peak hydrocarbon accumulation occurred in the Cenomanian while generation/ expulsion reached a peak at the start of the Cenozoic.
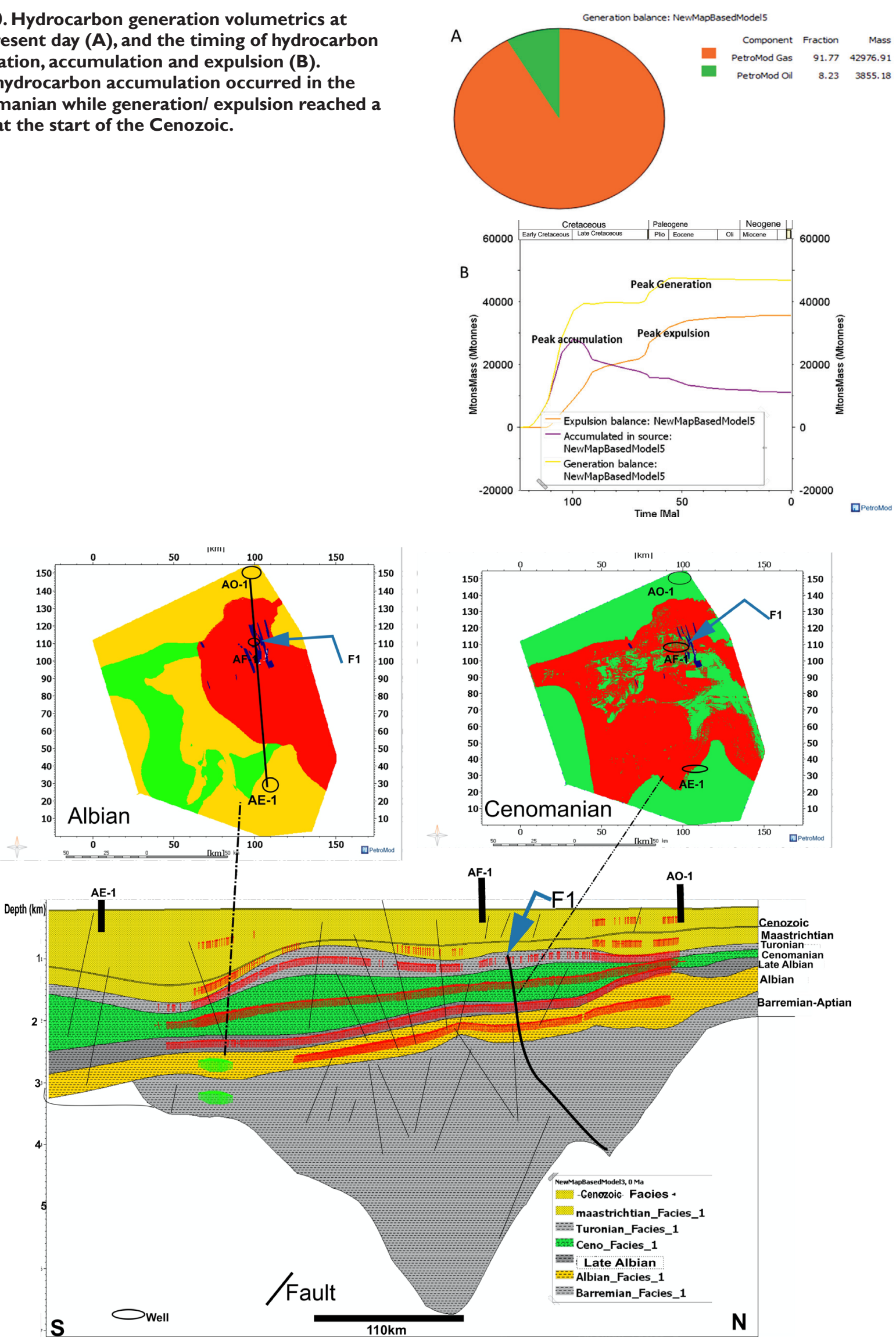

Fig. I I. Hydrocarbon migration within the Albian (A) and Cenomanian (B), and 2D profile of hydrocarbon migration (C) (red, gas; green, oil). Model dimensions are 150 by $150 \mathrm{~km}$. Faults are blue polygons marked on the maps; the reactivated listric fault FI is labelled on the map and the cross-section. Oil migrated within the Albian reservoir units, and gas in both the Albian and Cenomanian. 
Table 3. Fault ages and type/ properties used for the simulation.

\begin{tabular}{|c|c|c|c|c|}
\hline Name & Fault Type & Age From (Ma) & Age To (Ma) & Fault Property \\
\hline F42 & Normal & 110 & 109 & Closed \\
\hline F41 & Lineament & 125 & 124 & Open \\
\hline F40 & Normal & 108 & 93 & Closed \\
\hline F39 & Normal & 108 & 93 & Closed \\
\hline F38 & Normal & 110 & 109 & Closed \\
\hline F37 & Normal & 108 & 93 & Closed \\
\hline F36 & Normal & 113 & 111 & Closed \\
\hline F35 & Normal & 110 & 109 & Closed \\
\hline F34 & Normal & 67 & 65 & Closed \\
\hline F33 & Polygonal & 65 & 15 & Closed \\
\hline F32 & Normal & 110 & 93 & Closed \\
\hline F31 & Polygonal & 67 & 65 & Closed \\
\hline F30 & Normal & 120 & 118 & Open \\
\hline F29 & Normal & 120 & 118 & Open \\
\hline F28 & Normal & 120 & 118 & Open \\
\hline F27 & Polygonal & 65 & 15 & Closed \\
\hline F26 & Normal & 93 & 65 & Closed \\
\hline F25 & Normal & 120 & 118 & Open \\
\hline F24 & Antithetic & 110 & 93 & Closed \\
\hline F23 & Antithetic & 112 & 110 & Closed \\
\hline F22 & Antithetic & 112 & 110 & Closed \\
\hline F21 & Normal & 120 & 115 & Open \\
\hline F20 & Normal & 120 & 110 & Open \\
\hline F19 & Normal & 110 & 67 & Closed \\
\hline F18 & Normal & 112 & 95 & Closed \\
\hline F19 & Normal & 110 & 95 & Closed \\
\hline F18 & Normal & 112 & 91 & Closed \\
\hline F17 & Normal & 120 & 115 & Open \\
\hline F16 & Normal & 112 & 93 & Closed \\
\hline F15 & Normal & 120 & 115 & Open \\
\hline F14 & Normal & 120 & 115 & Open \\
\hline F13 & Normal & 120 & 115 & Open \\
\hline F12 & Normal & 112 & 110 & Closed \\
\hline F11 & Normal & 112 & 110 & Closed \\
\hline F10 & Normal & 112 & 110 & Closed \\
\hline F9 & Normal & 110 & 67 & Closed \\
\hline F8 & Normal & 112 & 110 & Closed \\
\hline F7 & Normal & 93 & 65 & Closed \\
\hline F6 & Normal & 93 & 65 & Closed \\
\hline $\mathrm{F} 5$ & Normal & 110 & 93 & Closed \\
\hline $\mathrm{F} 4$ & Normal & 110 & 93 & Closed \\
\hline F3 & Normal & 112 & 110 & Closed \\
\hline $\mathrm{F} 2$ & Normal & 112 & 110 & Closed \\
\hline $\mathbf{F 1}$ & Listric Normal & 124 & 65 & Open \\
\hline
\end{tabular}

m fits with 1D downhole temperature models at well locations, which increase from the northern part of the study area (well AO-1) to the south (well AE-1) (Fig. $5 \mathrm{~A}-\mathrm{C}$ ). Consistency between measured and modelled temperatures at the well locations supports the validity of the models.

\section{Erosion and thermal maturity}

Uplift and erosion of the Southern Africa continental hinterland during the Cenomanian (Braun et al., 2014) may have resulted in elevated sediment transport to the coastal basins, causing overall progradation of the Orange Basin fill (Dingle et al., 1983). The highest average global climatic temperatures during the Cretaceous occurred in the Cenomanian (Caldeira et $a l ., 1991)$, and the elevated transports of sediments to the coastal basins may have been aided by high rates of denudation in the hinterland. Significant thermal effects within the sedimentary succession due to high sedimentation rates (Lucazeau and Le Douaran, 1985) coupled with a basal heat pulse are evidenced by the modelled VR values which are less than the measured VR in well AO-1 in the north of the study area (red circle in Fig. 6A). In well AF-1 in the centre of the study area, modelled VR values in the Cenomanian are likewise less than measured values (Fig. 6B) due to the high rates of sedimentation and the associated thermal effects (Lucazeau and Le Douran,1985). At well AE-1 in the south (Fig. 6C), a similar effect is seen in the Cenomanian succession, in which modelled VR values are less than measured values.

By contrast, in the Turonian - Coniacian succession, the measured VR is less than the modelled VR in well AO-1 in the north of the study area (blue circle, Fig. 
Fig. 1 2. 3D model of 36 faults used for the study, including fault FI (see text). Model size is $150 \mathrm{~km}$ by $150 \mathrm{~km}$.

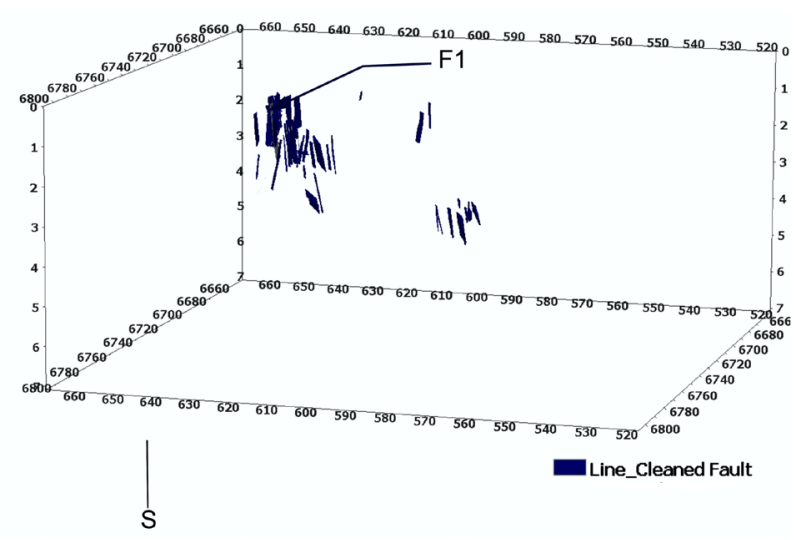

A
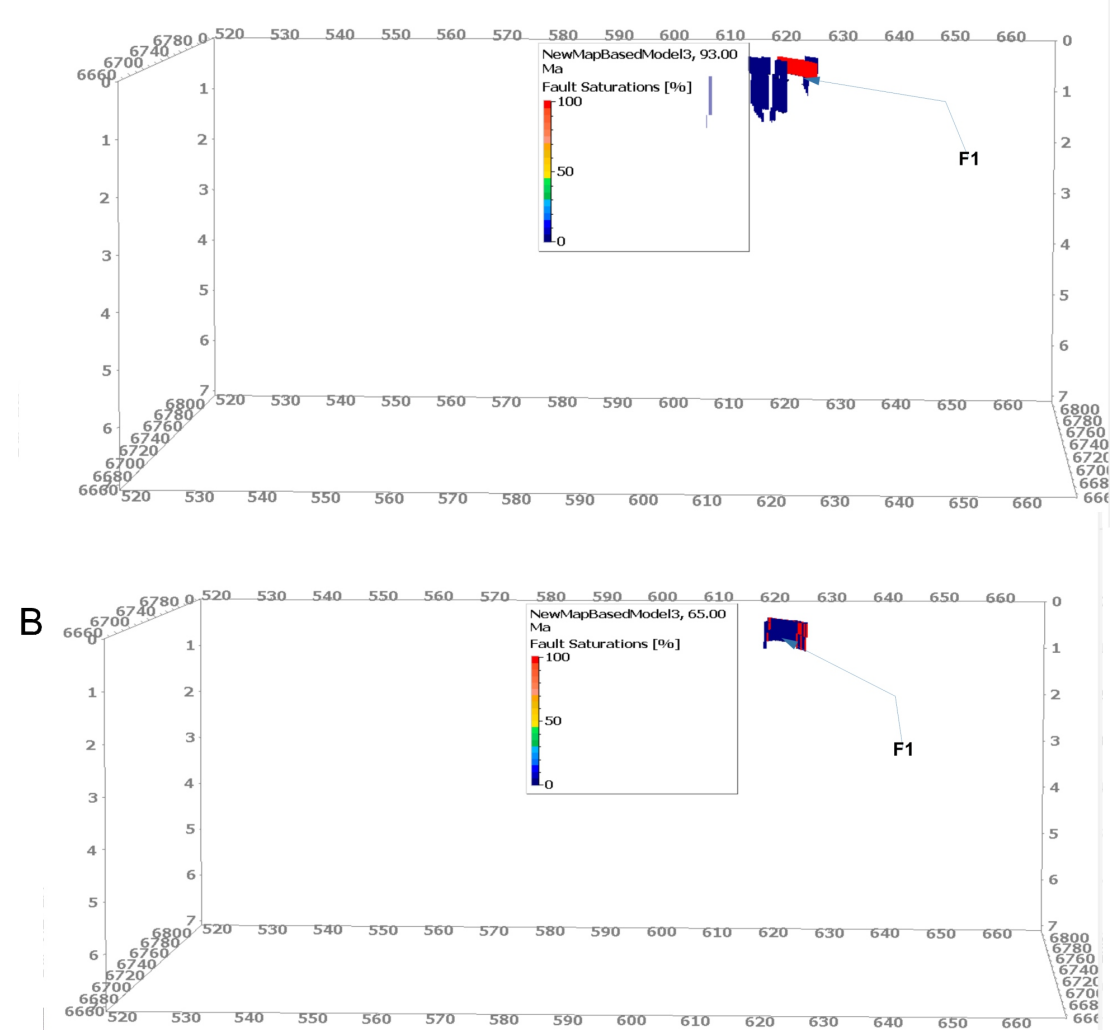

Fig. 13. The synrift listric fault FI trapped gas with 100\% efficiency at $93 \mathrm{Ma}$ (A); the efficiency declined to an estimated $15 \%$ at $65 \mathrm{Ma}$ (B) (red, gas; green, oil). Model dimensions 150 by $150 \mathrm{~km}$; loss of saturation is linked to reactivation of the Orange Basin in the Late Cretaceous.

6A), probably due to localised erosion at this location. For the Turonian, modelled and measured VR values match closely in well AF-1, suggesting there was little erosion at this location (Fig. 6B). No measured VR values for the Turonian in well AE-1 to the south were available with which to calibrate the thermal maturity.

In all the wells, modelled temperatures for the Barremian - Aptian source rock fit well with measured temperature values and are consistent with the map of temperature variations (Fig. 7A). The map of modelled variations in vitrinite reflectance for the Barremian Aptian interval at the present-day (Fig. 8A) indicates values of $\sim 0.5-0.6 \% \mathrm{R}_{\mathrm{o}}$ at well $\mathrm{AO}-1, \sim 0.8-1.0 \% \mathrm{R}_{\mathrm{o}}$ at well AF-1 and $\sim 1.0-1.2 \% \mathrm{R}_{\mathrm{o}}$ around well AE-1 (Fig.
$8 \mathrm{~A})$. The map shows that the interval has not reached the oil generation window in the northern part of the study area, while the central and southern areas are in the late gas generation window.

\section{Petroleum generation and migration}

The map of modelled variations in transformation ratio of the Barremian - Aptian source rock interval (Fig. 9A) shows that hydrocarbon generation started in the central portion of the study area, where the present-day transformation ratio is $\sim 100 \%$. The transformation ratios decline to both south and north ( $70 \%$ and less than $5 \%$, respectively). 


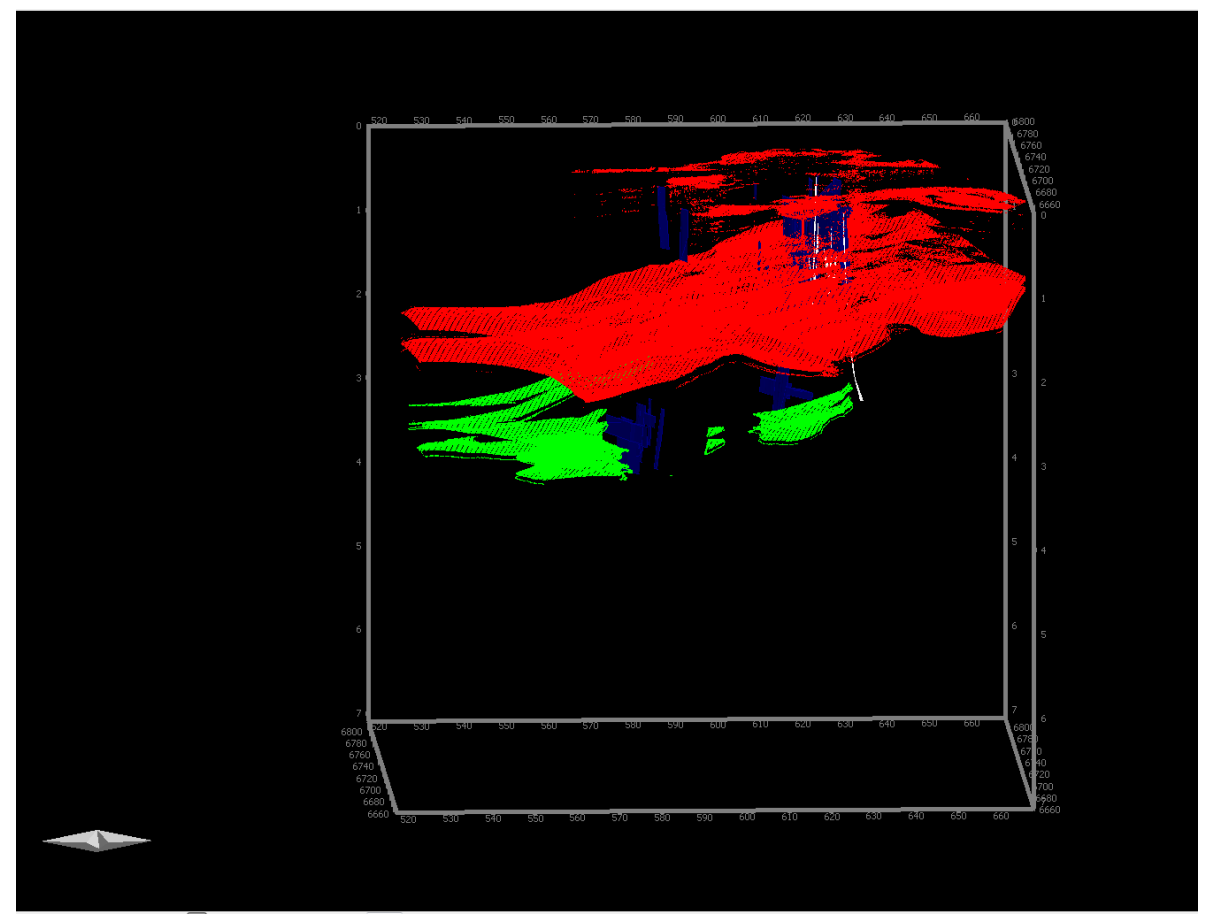

Fig. 14.3D hydrocarbon migration model of the study area at present day with the depth horizon maps and hydrocarbon components; gas, red; oil, green; fault pillars in blue. Water component has been filtered. Model grid lies between X $520 \mathrm{~km}$ and $660 \mathrm{~km}$ and $Y 6670 \mathrm{~km}$ by $6800 \mathrm{~km}$. Model dimensions are $150 \mathrm{~km}$ by $150 \mathrm{~km}$.

The onset of petroleum generation occurred around $116 \mathrm{Ma}$ (late Aptian; Fig. 10B), before the late Albian claystones and the Turonian shales (potential seal) were deposited. Hartwig (2014) proposed a similar age for the onset of petroleum generation. Barton et al. (1993) and Muntingh (1993) showed that the source rocks had reached sufficient maturity for gas generation to occur in the central shelf area in the Albian with potential for oil generation in more distal parts.

In the current model, expulsion (migration) began at about $110 \mathrm{Ma}$ (Albian) and reached a peak at the end of the Cretaceous, coinciding with a phase of Late Cretaceous margin uplift. High transformation ratios, possibly associated with pressure build-ups, facilitated the significant expulsion of hydrocarbons. The potential occurrence of sand lenses within the source rock unit may also have driven the significant expulsion of hydrocarbons at a local scale (c.f. Fan et al., 2019). The timing of expulsion also coincided with the onset of secondary cracking in the Late Cretaceous which generated additional gas in the southern Orange Basin (Hartwig, 2014).

The calibration of the 3D hydrocarbon generation model with the 1D generation models (Fig. 9AD) indicates that the model is accurate. The transformation ratio at well AF-1 is $100 \%$; however, there is little evidence of transformation of kerogen into hydrocarbons at well AO-1 in the north of the study area (Fig. 9B); and only about $60 \%$ transformation has taken place at well AE-1 in the south (Fig. 9D). These observations fit well with the 3D model.
The model results suggested that 42,977 million tons of gas have been generated by both primary and secondary cracking processes, while 3855 million tons of oil have been generated. The migration model indicates that hydrocarbons migrated vertically from the source rock into overlying Albian and Cenomanian carrier beds (Fig. 11A, B and C). Apart from faults which may serve as conduits for migration, the major potential carrier beds are suggested to be Cenomanian and Albian sandstones (Fig. 11A-C). Gas migration within these carriers units is random, while hydrodynamic factors may have favoured the migration of oil down-dip (i.e. westwards) in the study area (Fig.11 A-C).

\section{Fault controls on hydrocarbon migration}

The study suggests that a reactivated listric fault played a significant role in hydrocarbon migration. Previous studies in the Orange Basin have reported the role of faults in the development of hydrocarbon escape features such as chimneys and pockmarks (BenAvraham et al., 2002; Kuhlmann et al., 2010; Hartwig et al., 2012). In the present model, due to limited data with which to estimate the shale gouge ratio, faults were defined as open to migration during the syn-rift period and closed in the post-rift period. Although this is only an approximation, Bjørlykke et al. (2005) reported that post-rift faults, especially faults more than $1000 \mathrm{~m}$ deep, are generally closed to fluid flow because of cementation along the fault planes except where they are kept open by hydraulic pressure, which 
may be common in compressional settings. In addition, faults less than $1000 \mathrm{~m}$ deep may act as fluid conduits in subsiding basins (Clayton and Hay, 1994).

With this in mind, some reactivated faults in the Orange Basin could serve as conduits for hydrocarbon migration. Thus, the model suggests that the reactivated listric fault F1 trapped gas at $93 \mathrm{Ma}$, with a gas saturation along the fault plane of $100 \%$ (Fig. 13A); the saturation was reduced by $65 \mathrm{Ma}$, and the present-day gas saturation is only $\sim 15 \%$ (Fig. 13B). The reduction in gas saturation along the fault plane is attributed to episodes of margin uplift in the Late Cretaceous and Miocene, which resulted in the development of breakthrough migration paths and the Cenozoic migration of trapped gas. This observation is consistent with Hartwig (2014) who suggested that hydrocarbon migration from the reservoirs in the southern Orange Basin was triggered by Late Cretaceous uplift, and that the youngest episode of migration coincides with a phase of Miocene erosion.

\section{Model assumptions and uncertainties.}

Basin and petroleum systems modelling is often associated with assumptions which may lead to high uncertainty in the results, depending on the data available. In the present study, a combination of 2D and 3D seismic data was used to create the depth maps used as inputs in the model. While the geometry (spatial extent) of the faults mapped on the $3 \mathrm{D}$ seismic data can be tracked, the fault geometry mapped on the 2D data could not be tracked. Therefore, the probability of finding a structural closure within the coverage of the $2 \mathrm{D}$ data is minimal and reduces the possibility of locating hydrocarbon accumulations in the study area. However, this is not a sufficient reason to conclude that there is no chance of hydrocarbon accumulations in the area.

In addition, due to a lack of shale gouge ratio data, an assumption was made regarding the hydraulic property of the faults in that syn-rift faults are open while post-rift faults are closed. This assumption introduced an uncertainty about the hydraulic properties of the faults.

\section{Comparison with other conjugate passive margins and direction of future exploration}

A feature that the Orange Basin has in common with the Santos Basin (offshore Brazil) and with offshore Uruguay is the occurrence of the Barremian - Aptian source rock (Broad et al., 2007; Clemente; 2013; Morales et al., 2017). Hydrocarbon indicators such as chimneys, pockmarks and bright spot anomalies are prominent in the Orange Basin (Boyd et al., 2012), and in offshore Uruguay where normal and polygonal fault systems influenced the vertical migration of hydrocarbons (Morales et al., 2017).
The chronostratigraphy of the Orange Basin (Fig. 2A) shows that sediment deposition began in the Hauterivian, whereas in the Santos Basin, deposition began during the Barremian-Aptian (Clemente, 2013). Opening of the South Atlantic took place from south to north during the break-up of Gondwana which was initiated in the Late Jurassic (Clemente, 2013).

In the Santos Basin, source rocks are present within the Barremian-Aptian Itapema succession which is equivalent to the source rock in the Orange Basin (Fig. 11C). Similar depositional processes occurred in the Orange and Santos Basins until the late Aptian, after which the development of salt structures in the Santos Basin controlled subsequent sediment deposition and hydrocarbon accumulation/ migration. Hydrocarbon accumulations in the basin mainly occur in carbonates in the pre-salt succession but also occur in post-salt calcarenites and siliciclastic turbidites (Bruhn et al., 2017). In the Orange Basin offshore South Africa by contrast, the main gas discovery occurs within an Albian siliciclastic reservoir, with additional potential reservoirs in the Cenomanian.

Cenozoic turbidites also probably occur in the Orange Basin together with widespread Late Cretaceous slumps, gravity flows and mass transport deposits (de Vera et al., 2010, Scarselli et al., 2016). Cenozoic turbidites have also been reported in the conjugate margins offshore Uruguay and in the Santos Basin (Rodriguez et al., 2019; Bruhn et al., 2017). Exploration of the turbidites play offshore Uruguay has not been successful largely due to lack of charge access, explained by the distance of the reservoirs from a source rock kitchen and by the absence of faults as migration pathways (Rodriguez, et al., 2019). However, the presence of reactivated regional faults in the Orange Basin, such as fault F1 identified in the present study, could allow charging of the proposed Cenozoic turbidite reservoirs.

\section{CONCLUSIONS}

This study investigated the timing of hydrocarbon generation and expulsion from Barremian - Aptian source rocks in the northern section of the Orange Basin, offshore South Africa, and the influence of faults on hydrocarbon migration.

The vitrinite reflectance (VR) models show that the modelled VR for the Cenomanian is lower than the measured VR. Thermal maturation of sediments during the Cenomanian was likely influenced by high sedimentation rates which may have resulted in significant heat absorption in the thick sedimentary succession in this part of the basin. Also, evidence from the VR and transformation ratio (TR) models indicates that the source rock is immature in the northern section of the basin at the present-day, leading 
to the conclusion that the model is more sensitive to spatial heatflow variations than to burial variations. The thickness of the Barremian-Aptian sequence in the central portion of the study area influenced the relatively earlier generation of hydrocarbons in the late Aptian, with a modelled present-day transformation ratio there of $100 \%$. The TR declines to both the north and south, to less than $5 \%$ and $60 \%$ respectively.

Source rocks in the northern part of the study area close to well AO-1 are thermally immature. Rapid sedimentation and accompanying compaction during the Cenomanian coupled with increased basal heat flow led to peak generation of hydrocarbons within the source rock. Expulsion of hydrocarbons from the source rock started in the Albian (110 Ma), reaching a peak by the end of the Cretaceous coinciding with uplift of the SW African margin.

Hydrocarbon migration occurred within the Cenomanian and Albian stratal units. Oil is modelled to have migrated vertically and laterally westwards within the Albian unit, while gas migration was random in both the Cenomanian and Albian units. The westward migration of oil may have been influenced by hydrodynamic factors which favoured migration towards the deeper-water, distal portion of the study area. A reactivated synrift listric fault (referred to as F1) has served as a major control on hydrocarbon migration, with an estimated present-day gas saturation of $\sim 15 \%$ along the fault plane. Reactivation of the fault occurred during different episodes of uplift of the southern Africa margin.

Future exploration for oil plays should therefore move from the continental shelf of the Orange Basin to more distal, deeper-water areas.

\section{ACKNOWLEDGEMENTS}

Appreciation goes to the National Research Foundation for funding this research through the South African Research Chair Initiative linked to Ray Durrheim; to the Petroleum Agency of South Africa for data provision; and the division of Postgraduate Studies, University of the Western Cape, for institutional support. The Schlumberger Oilfield Corporation is appreciated for software support. The authors acknowledge reviews of a previous version of the paper by Ansgar Wanke (University of Namibia) and an anonymous referee.

\section{Data availability}

Data are available on request from the corresponding author and in agreement with the Petroleum Agency of South Africa.

\section{Author contributions}

Chris Samakinde: data collection, conceptualisation, technical content and write-up.
Jan van Bever Donker: proof-reading, editing, manuscript structuring, interpretations and advice.

Ray Durrheim: proof-reading, editing, manuscript structuring and advice.

Musa Manzi: proof-reading, editing manuscript structuring and advice.

\section{Competing interests}

There are no competing interests from any of the authors for the manuscript and the data.

\section{REFERENCES}

ADEKOLA, S.A., AKINLUA, A. and MANGELSDORF, K., 2012. Organic geochemical evaluation of Cretaceous shale samples from the Orange Basin, South Africa. Applied Geochemistry 27, 1633-1642.

ALDRICH, J., ZILINSKI, R., EDMAN, J., LEU,W., BERGE, T. and CORBETT, K., 2003. Documentation of a new petroleum system in the South Atlantic (Abstract). AAPG Annual Convention, May, I I-14, 2003.

ATHY, L. F., 1930. Density, porosity, and compaction of sedimentary rocks. AAPG Bulletin I4, I-22.

BARTON, K.R., MUNTINGH, A. and NOBLE, R.D.P., 1993. Geophysical and geological studies applied to the hydrocarbon exploration on the West coast margin of South Africa. Extended Abstracts of the third International Congress of the Brazilian Geological Society, Rio De Janeiro, 1993.

BEN-AVRAHAM, Z., SMITH, G., RESHEF, M. and JUNGSLAGER, E.H.A., 2002. Gas hydrate and mud volcanoes on the southwest African continental margin off South Africa. GSA Bulletin 30, 927-930.

BJØRLYKKE, K., HØEG, K., FALEIDE, J.I. and JAHREN, J., 2005. When do faults in sedimentary basins leak? Stress and deformation in sedimentary basins; examples from the North Sea and Haltenbanken, offshore Norway. AAPG Bulletin 89, I019-1031.

BOYD, D., ANKA, Z., DI PRIMIO, R., KUHLMANN, G, and DE WIT, M.J., 20I I. Passive margin evolution and controls on natural gas leakage in the orange basin, South Africa. South African Journal of Geology, I I 4, 4I 5-432.

BRAUN, J., GUILLOCHEAU, F., ROBIN, C., BABY, G. and JELSMA, H., 20l4. Rapid erosion of the Southern Africa Plateau as it climbs over a mantle super swell. Journal of Geophysical Research: Solid Earth. I I 9. 10.1002/2014JB0I0998.

BROAD, D.S., JUNGSLAGER, E.H.A., McLACHLAN, I.R. and ROUX, J., 2007. Offshore Mesozoic Basins. In: M.R Johnson, C.R Anhaeusser and R.J. Thomas (Eds), The Geology of South Africa / Council for Geoscience, Pp 553-565.

BROWN, L. F., BROWN, L.F, JR., BENSON, J. M., BRINK, G.J., DOHERTY, S., JOLLANDS, A., JUNGSLAGER, E.H.A., KEENAN, J.H.G., MUNTINGH, A. and VAN WYK, N.J.S., 1996. Sequence stratigraphy in offshore South Africa divergent basins. An atlas on exploration for Cretaceous lowstand traps by SOEKOR (Pty) Ltd. AAPG Studies in Geology 4I, I 84 PP.

BRUHN, C. H. L., PINTO,A. C. C., JOHANN, P. R. S., BRANCO, C. C.M., SALOMÃO, M. C. and FREIRE, E. B., 2017. Campos and Santos basins: 40 years of reservoir characterization and management of shallow- to ultra-deep water, post- and presalt reservoirs - historical overview and future challenges. Offshore Technology Conference. Doi: 10.4043/28I59-ms

CALDEIRA, K. and RAMPINO,M.R., 199I.The mid-Cretaceous super plume, carbon dioxide, and global warming. Geophysical Research Letters I8, 987-990 .doi: I0.1029/9 Ig101237.

CAMPHER, C., 2009. Geological Modelling of the offshore 
Orange Basin, west coast of South Africa. Unpublished M.Sc thesis, University of the Western Cape. 199 pp.

CLAYTON, C.J. and HAY, S.J., 1994. Gas migration mechanisms from accumulation to surface. Bulletin Geologic Society Denmark 4I, I2-23.

CLEMENTE, P., 2013. Petroleum geology of the Campos and Santos basins, Lower Cretaceous Brazilian sector of the South Atlantic margin. Denmark Technical University study, I-33. https://doi.org//0.13|40/2.I.1290.400 I

DE VERA, J., GRANADO, P., and McCLAY, K., 20I0. Structural evolution of the Orange Basin gravity-driven system, offshore Namibia. Marine and Petroleum Geology, 27, 223-237.

DINGLE, R.V., SIESSER, W.G., and NEWTON, A.R., I 983, Mesozoic and Tertiary geology of Southern Africa. Balkema, Rotterdam, I 2 I, 375 Pp.

FADIPE, O.A., CAREY, P.F., AKINLUA, A. and ADEKOLA, S.A., 20II. Provenance, diagenesis and reservoir quality of the lower Cretaceous sandstone of the Orange Basin, South Africa. South African Journal of Geology I I 4, 433-448.

FAN, B., SHI, L., LI,Y., ZHANG, T., LU, L. and SHIKAI, T., 2019. Lithologic heterogeneity of lacustrine shale and its geological significance for shale hydrocarbon - a case study Zhangjiatan Shale. Open Geosciences, I I, I0 I-I I 2.

FAULKNER, P. A., 2000. Tectonic and Thermal Evolution of South Atlantic Marginal Basins. Unpublished Ph.D. thesis, University of Cambridge, UK, I |4- I37.

GERRARD, I. and SMITH, G. C., I 982. Post-Paleozoic succession and structure of the south-western African continental margin. In: Watkins, J.S. and Drake, C.L. (Eds), Studies in Continental Margin Geology: AAPG Memoir, 34, 49-74.

GOUTORBE, B., LUCAZEAU, F. and BONNEVILLE, A., 2008. The thermal regime of South African continental margins. Earth and Planetary Science Letters 267, 256-265.

GRANADO, P., VERA, J. and McCLAY, K., 2009. Tectonostratigraphic evolution of the Orange Basin, SW Africa. Trabajos de Geología, 29, 32I.

HANTSCHEL,T., KAUERAUF,A. andWYGRALA, B., 2000. Finite element analysis and ray tracing modelling of petroleum migration. Marine and Petroleum Geology, I 7, 815-820.

HAQ, B.U., HARDENBOL, L.J., and VAIL, P. R., 1987. Chronology of fluctuating sea levels since the Triassic. Science 235 (4793), II56-I I67.

HARDENBOL, ., et al., 1998. Mesozoic and Cenozoic sequence chronostratigraphic chart. In: Graciansky, P.C.D., Hardenbol, J., Jacquin, T. and Vail, P. R. (Eds), Mesozoic and Cenozoic Sequence Stratigraphy of European Basins. Society of Sedimentary Geology.

HART, N. R., STOCKLI, D. F., LAVIER, L. L. and HAYMAN, N. W., 2017.Thermal evolution of a hyper-extended rift basin, Mauléon Basin, western Pyrenees. Journal of Tectonics, 36, $1103-1128$.

HARTWIG, A., 20I4. Hydrocarbon migration and leakage dynamics of the Orange Basin, South Africa. Berlin: Technischen Universität Berlin. 256 pp.

HARTWIG, A., ANKA, Z. and DI PRIMIO, R., 2012. Evidence of a widespread paleo-pockmarks field in the Orange Basin: An indication of an early Eocene massive fluid escape event. Journal of Marine Geology, 332-334, 222-234.

HERBIN, J.P., MULLER, C., GRACIANSKY, P.C. De, JACQUIN, T., MAGNIEZ-JANNIN, F. and UNTERNEHR, P., 1987. Cretaceous anoxic event in the South Atlantic. Revista Brasileria de Geociencia, I 7, 92-99.

HIRSCH, K.K., SCHECK-WENDEROTH, M., VAN WEES, J.D., KUHLMANN, G., and PATON, D. A., 20I0. Tectonic subsidence history and thermal evolution of the Orange Basin. Marine and Petroleum Geology 27, 565-584.

HIRSCH, K.K., SCHECK-WENDEROTH, M., PATON, D.A., and BAUER, K., 2007. Crustal structure beneath the Orange Basin, South Africa. South African Journal of Geology I I 0 (2-3), 249-260.
IES, 2007. PetroMod 2D Advanced, Tutorial Software Version I0. IES, GmbH Integrated Exploration System, Aachen, IES, $\mathrm{GmbH}$ Integrated Exploration System, Aachen, I39 pp.

JIKELO, A.N., I 999. Oil and Gas potentials of the South African offshore basins. Journal of African Earth Sciences 28 (4), 33.

JUNG, G., PRANGE, M. and SCHULZ, M., 20I4. Uplift of Africa as a potential cause for Neogene intensification of the Benguela upwelling system. Nature Geoscience, 7, 74I-747.

JUNGSLAGER, E. H.A., I 999. Petroleum habitat of the Atlantic margin of South Africa. In: Cameron, N.R., Bate, R. H and Clure, V. S. , (Eds), The oil and gas habitat of the South Atlantic. Geol. Soc. Lond. Spec. Publ. I 53, I 53-168.

KOUNOV,A.,VIOLA, G., DEWIT, M.,ANDREOLI,M.A.G., 2009. Denudation along the Atlantic passive margin: new insights from apatite fission-track analysis on the western coast of South Africa. Geological Society of London, Special Publication 324, 287-306.

KUHLMANN, G., ADAMS, S., CAMPHER, C.,VAN DER SPUY, D., DI PRIMIO, R. and HORSFIELD, B., 20I0. Passive margin evolution and its controls on natural gas leakage in the southern Orange Basin, blocks 3 and 4, offshore South Africa. Marine and Petroleum Geology, 27, 973-992

LIGHT, M. P. R., MASLANYJ, M. P., GREENWOOD, R. J., and BANKS, N. L. 1993. Seismic sequence stratigraphy and tectonics offshore Namibia. In: G. D. WILLIAMS and A. DOBB (Eds), Tectonics and seismic sequence stratigraphy. Geol. Soc. Lond. Spec. Publ. 7I, I63-191.

LUCAZEAU, F. and Le DOUARAN,S. 1985. The blanketing effect of sediments in basins formed by extension: a numerical model.Application to the Gulf of Lion andViking graben. Earth and Planetary Science Letters, 74, 92-102.

MACDONALD, D., GOMEZ-PEREZ, I., FRANZEZE, J., SPALLETTI, L., LAWVER, L.,GAHANGAN, L, DALZIEL, I., THOMAS, C., TREWIN, N, HOLE, M. and PATON, D., 2003. Mesozoic break-up of SW Gondwana: Implication for regional hydrocarbon potential of Southern \South Atlantic. Marine and Petroleum Geology, 20, 287-308.

MAGARA, K., 1980. Evidences of primary migration. AAPG Bulletin, 64, 2108-2117.

McKENZIE, D., 1978. Some remarks on the development of sedimentary basins: Earth and Planetary Science Letters, 40, I; 25-32.

McMILLAN, I.K., 2003. Foraminiferally defined biostratigraphic episodes and sedimentation pattern of the Cretaceous drift succession (Early Barremian to Late Maastrichtian) in seven basins on the South African and southern Namibian continental margin. South African Journal of Science 99, 537-576.

MENZIES, M.A., KLEMPERER, S.L., EBINGER, C.J., BAKER, J., 2002. Characteristics of volcanic rifted margins. In: Menzies, M.A., Klemperer, S.L., Ebinger, C.J., Baker, J. (Eds), Volcanic Rifted Margins. Geological Society of America Special Issue, Boulder, Colorado, I-14.

MORALES, E., CHANG, H., SOTO, VEROSLAVSKY, G., CONTI, B., DE SANTA ANA, $H_{\text {., }}$ and CORREA, F., 20I7. Speculative Petroleum Systems of the Punta del Este Basin (offshore Uruguay). Brazillian Journal of Geology, 47, 4 645-656.

MORGAN,W.J., 197I. Convection plumes in the lower mantle. Nature, 230, 42-43.

MUNTINGH, A., 1993. Geology, prospect in Orange Basin offshore western South Africa. Oil and Gas Journal, January 25, $106-108$.

NYBLADE, A. and ROBINSON, S.W., 1994. The African Superswell. Geophysical Research Letters 21 (9), 765-768.

PANG, X., JIANG, Z., ZUO, S. and LERCHE, I., 2006. Dynamics of Hydrocarbon Expulsion from Shale Source Rocks.Journal of Energy Exploration and Exploitation, 23, 333-356.

PEPPER, A.S., and CORVI, P. J., 1995. Simple kinetic models of petroleum formation. Part I: oil and gas generation from kerogen. Marine and Petroleum Geology, I 2, 291-319. 
PETERS, K.E., WALTERS, C. C. and MANKIEWICZ, P.., 2006. Evaluation of kinetic uncertainty in numerical models of petroleum generation. AAPG Bulletin, 90, 387-403.

PETROLEUM AGENCY SA, 2006. Petroleum Exploration Information and Opportunities. Petroleum Agency South Africa Brochure, 32 pp.

RODRIGUEZ, P.A., FERRO, S. and WEIJERMARS, R., 2019. Probabilistic techno-economic appraisal of prospective hydrocarbon resources in five turbidites, offshore Uruguay. Offshore Technology Conference. doi: 10.4043/29929-MS.

SAMAKINDE, C., VAN BEVER DONKER, J., DURRHEIM, R. and MANZI, M., 202I. Application of seismic stratigraphy in reservoir characterisation: a case study of the passive margin deposits of the northern Orange Basin, South Africa. Journal of Petroleum Exploration and Production Technology, I I, 45-6I. https://doi.org// 0.1007/s / 3202-020-01050-9

SAMAKINDE, C., VAN BEVER DONKER, J.M. and FADIPE, O., 2020. A combination of genetic inversion and seismic frequency attributes to delineate reservoir targets in offshore northern Orange Basin, South Africa. Open Journal of Geosciences, I 2, I-I I.

SAMAKINDE, C., OPUWARI, M. andVAN BEVER DONKER, M., 2016. The effects of clay diagenesis on some petrophysical properties of the lower Cretaceous sandstone reservoirs, Orange Basin, South Africa. South African Journal of Geology, I I 9, 187-202.

SCARSELLI, N., McCLAY, K. and ELDERS, C., 2016. Seismic geomorphology of Cretaceous megaslides offshore Namibia (Orange Basin): Insights into segmentation and degradation of gravity-driven linked systems. Marine and Petroleum Geology, 75, I5I-I80.

SCHNEIDER, F., POTDEVIN, J.L., WOLF, S. and FAILLE, I., 1996. Mechanical and Chemical Compaction model for Sedimentary basin simulators. Journal of Tectonophysics, 263, 307-317.

SEKIGUCHI, H. and OHTA H., 1977. Induced anisotropy and time dependency in clays. In: Murayama S, Schofield AN, editors. Proceedings of the 9th ICSMFE 1977; Specialty Session 9, p. 229.

SÉRANNE, M., and ANKA, Z., 2005. South Atlantic continental margins of Africa: a comparison of the tectonic vs. climate inter-play on the evolution of EquatorialWestAfrica and SW Africa margins. Journal of Africa Earth Sciences, 43, 283-300.

SLAGSTAD, T., MIDTTØMME K., RAMSTAD, R.K. and SLAGSTAD, D., 2008. Factors influencing shallow $(<1000 \mathrm{~m}$ depth) temperatures and their significance for extraction of ground-source heat. In: T.Slagstad (Ed.), Geology for Society, Geological Survey of Norway Special Publication, II, 99-109.

SWEENEY,J.J and BURNHAM,A.K., 1990. Evaluation of a simple model of vitrinite reflectance based on chemical kinetics. AAPG Bulletin 74 (I0), I559-I570.

VAN DER SPUY, D., 2003. Aptian source rocks in some South African Cretaceous Basins. In: Arthur, T. et al. (Eds), Petroleum Geology of Africa: New Themes and Developing Technologies. Geol. Soc. Lond., Spec. Publ. 207, 185-202.

VAN WEES, J.D., VAN BERGEN, F., DAVID, P., NEPVEU, M., BEEKMAN, F., CLOETINGH, S., and BONTÉ, D., 2009. Probabilistic tectonic heat flow modelling for basin maturation: Assessment method and applications. Marine and Petroleum Geology 26, 536-55I.

WAPLES, D.H. andWAPLES, J.S., 2004. A review and evaluation of specific heat capacities of rocks, minerals, and subsurface Fluids. Fluids and porous rocks. Natural Resources Research 2, I573-898I.

WEIGELT, E. and UENZELMANN-NEBEN, G., 2004. Sediment deposits in the Cape Basin: Indications for shifting ocean currents? AAPG Bulletin 88 (6), 765-780.

WELTE, D. H., HORSFIELD, B. and BAKER, D. R., 1997.Petroleum and basin evolution: insights from petroleum geochemistry, geology and basin modeling. Springer, Berlin, 534 pp.
WEN, Z., XU, H.,WANG, Z., HE, Z., SONG, C., CHEN, X., and WANG,Y., 2016. Classification and hydrocarbon distribution of passive continental margin basins. Petroleum Exploration and Development, 43, 5, 740-750.

WIGLEY, R.A. and COMPTON, J.S., 2006. Late Cenozoic evolution of the outer continental shelf at the head of the Cape Canyon, South Africa. Marine Geology. 226, I-23.

WYGRALA, B.P., 1989. Integrated study of an oil field in the southern Po basin, northern Italy. Ph.D. dissertation, Köln University:Jülich, Research Centre Jülich, Jul-Rep. 23।3, ISSN 0366-0885, 2 I 7 Pp. 